Prepared in cooperation with the Missouri Department of Natural Resources and the Missouri Department of Conservation

\title{
Assessment of an In-Channel Redistribution Technique for Large Woody Debris Management in Locust Creek, Linn County, Missouri
}
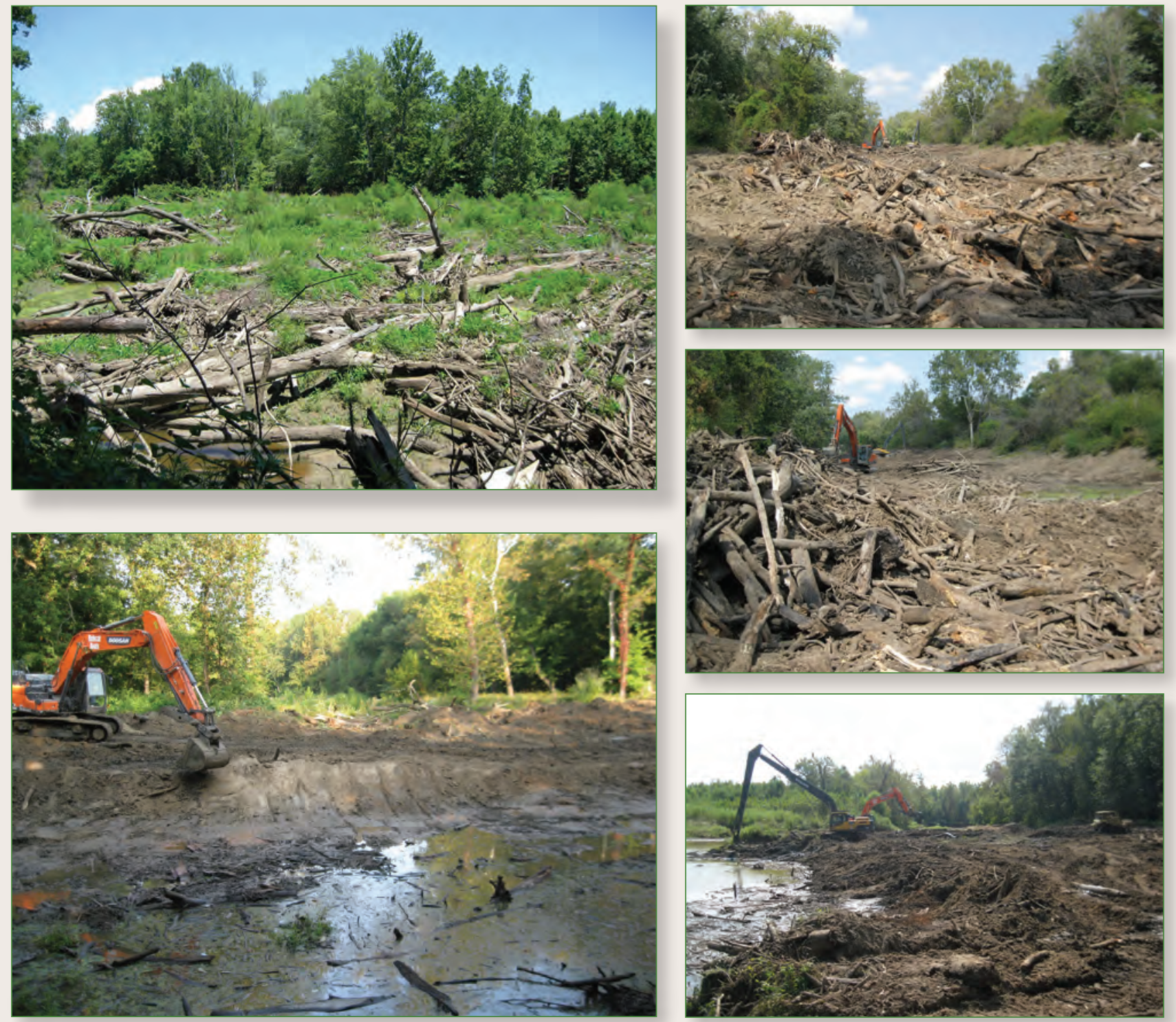

Scientific Investigations Report 2017-5120

U.S. Department of the Interior

U.S. Geological Survey

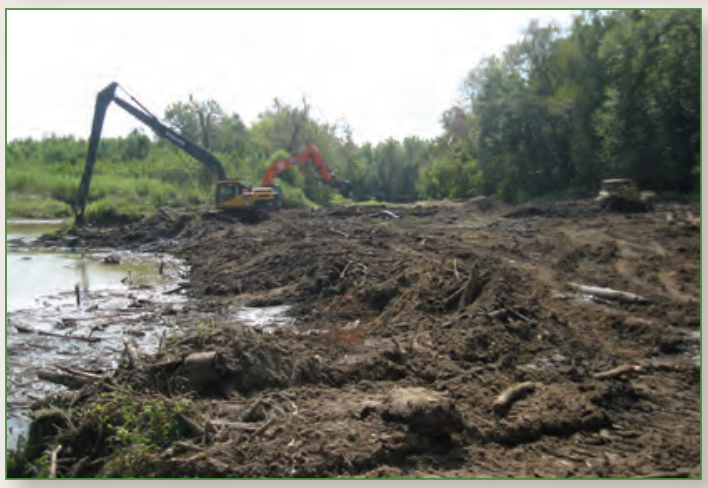



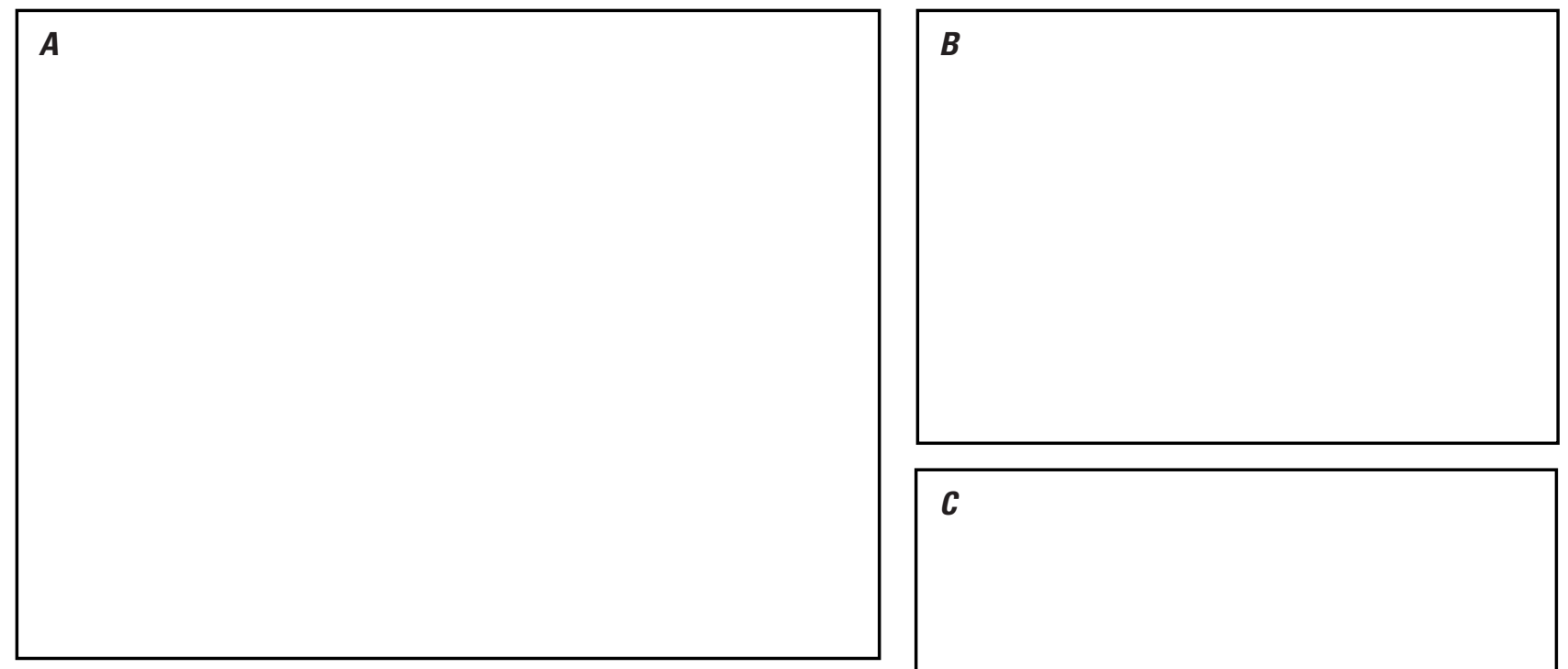

C

$E$

D

Cover. Photographs showing redistribution and treatment of large woody debris in Locust Creek at the north end of Pershing State Park, September 2017. A; Pre-redistribution and treatment. $B, C$, and $D$; During redistribution and treatment. E; Post-redistribution and treatment. Photographs by Tom Woodward, Missouri Department of Natural Resources, Pershing State Park. 


\section{Assessment of an In-Channel Redistribution Technique for Large Woody Debris Management in Locust Creek, Linn County, Missouri}

By David C. Heimann

Prepared in cooperation with the Missouri Department of Natural Resources and the Missouri Department of Conservation

Scientific Investigations Report 2017-5120 


\title{
U.S. Department of the Interior \\ RYAN K. ZINKE, Secretary
}

\section{U.S. Geological Survey William H. Werkheiser, Acting Director}

\author{
U.S. Geological Survey, Reston, Virginia: 2017
}

For more information on the USGS - the Federal source for science about the Earth, its natural and living resources, natural hazards, and the environment-visit https://www.usgs.gov or call 1-888-ASK-USGS.

For an overview of USGS information products, including maps, imagery, and publications, visit https://store.usgs.gov.

Any use of trade, firm, or product names is for descriptive purposes only and does not imply endorsement by the U.S. Government.

Although this information product, for the most part, is in the public domain, it also may contain copyrighted materials as noted in the text. Permission to reproduce copyrighted items must be secured from the copyright owner.

Suggested citation:

Heimann, D.C., 2017, Assessment of an in-channel redistribution technique for large woody debris management in Locust Creek, Linn County, Missouri: U.S. Geological Survey Scientific Investigations Report 2017-5120, 25 p., https://doi.org/10.3133/sir20175120.

ISSN 2328-0328 (online 


\section{Contents}

Abstract

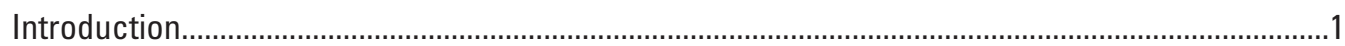

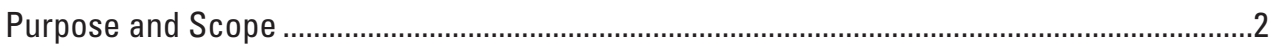

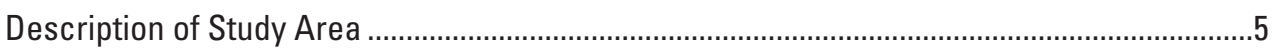

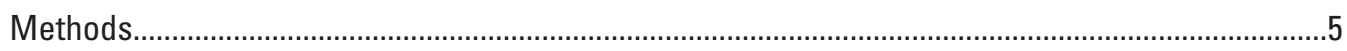

Hydrologic Characterization of Lower Locust Creek ...........................................................

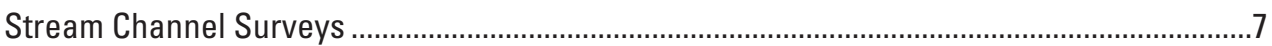

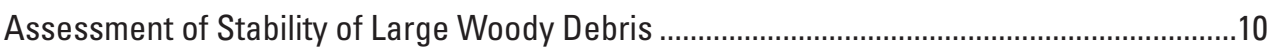

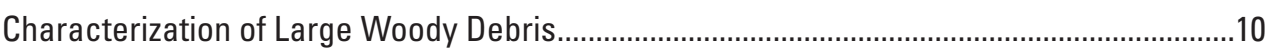

Assessment of In-Channel Large Woody Debris Redistribution Technique .....................................10

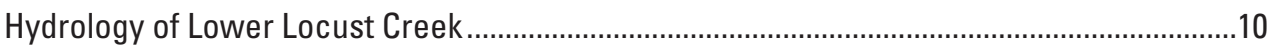

Comparison of Channel Metrics for Treated and Untreated Reaches......................................11

Channel Change and Large Woody Debris Stability after Treatment .......................................13

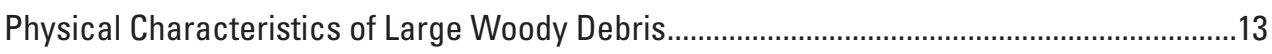

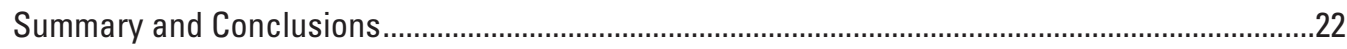

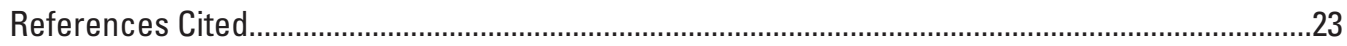

\section{Figures}

1. Map of study area and vicinity

2. Map of large woody debris treated reaches, large woody debris accumulation survey locations, and channel survey and channel bed material particle-size

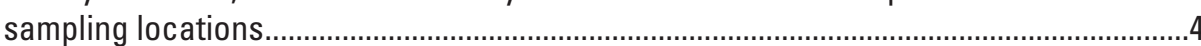

3. Map showing 2011 land use in the Locust Creek Basin..................................................

4. Hydrographs showing hypothetical temporal change in Locust Creek streamflow.........8

5. Hydrographs showing estimated temporal change in the bankfull streamflow threshold in Locust Creek hydrologic reaches 1-4, 1930-2016 water years.....................9

6. Plots showing frequency of Locust Creek bankfull streamflows by hydrologic reach developed using daily mean streamflow data from the U.S. Geological Survey streamgage Locust Creek near Linneus, Missouri, 1930-2016.

7. Plots showing frequency of Locust Creek bankfull streamflows by hydrologic reach developed using 15-minute streamflow data from the U.S. Geological Survey streamgage Locust Creek near Linneus, Missouri, 2001-2016.

8. Plots showing distribution of Locust Creek bankfull channel cross-sectional area; bankfull width; bankfull width-depth ratio; and bankfull streamflow capacity for treated and untreated reaches by longitudinal channel distance.

9. Plots showing the distribution of Locust Creek bankfull channel cross-sectional area; bankfull width; bankfull width-depth ratio; and bankfull streamflow capacity by year of large woody debris treatment

10. Boxplot showing the distribution of particle-size classes of Locust Creek bed material samples from reaches with redistribution of large woody debris (treated) and from untreated reaches.

11. Graphs showing comparison of selected channel cross sections surveyed in 1996 and 2015 in treated and untreated reaches of Locust Creek. 
12. Photographs and field notes documenting the status of redistributed large woody debris in the Locust Creek 2008 treatment reach during 2010-13...

13. Photographs and field notes documenting the status of redistributed large woody debris in the Locust Creek 2009 treatment reach during 2010-13.

\title{
Tables
}

1. Large woody debris position and decay class category descriptions 10

2. Distribution of Higgins Ditch, Locust Creek, and Dobbins Cut plus Muddy Creek streamflows through bridge openings at U.S. Highway 36 at Pershing State Park ........11

3. Comparison of bankfull cross-sectional channel area, bankfull channel width, bankfull width-depth ratio, and bankfull streamflow capacity in Locust Creek reaches treated with mechanical redistribution of large woody debris and in untreated reaches.

4. Results of dry-sieve analyses of particle-size distribution of composited bed material samples collected at surveyed cross sections in Locust Creek. link

5. Comparison of selected channel characteristics from 1996 and 2015 cross section surveys in treated and untreated reaches. 18

6. Physical characteristics of 100 pieces of large woody debris sampled from selected jams in the Locust Creek study area, April 2015 to March 2016. link

\section{Abbreviations}

\author{
DGPS Differential Global Positioning System \\ HR hydraulic reach \\ LWD large woody debris \\ MDC Missouri Department of Conservation \\ MoDNR Missouri Department of Natural Resources \\ NWIS National Water Information System \\ USGS U.S. Geological Survey
}




\title{
Assessment of an In-Channel Redistribution Technique for Large Woody Debris Management in Locust Creek, Linn County, Missouri
}

\author{
By David C. Heimann
}

\section{Abstract}

The U.S. Geological Survey, in cooperation with the Missouri Department of Conservation and Missouri Department of Natural Resources, completed a study to assess a mechanical redistribution technique used for the management of large woody debris (LWD) jams in Locust Creek within Pershing State Park and Fountain Grove Conservation Area, Linn County, Missouri. Extensive LWD jams were treated from 1996 to 2009 using a low-impact technique in which LWD from the jams was redistributed to reopen the channel and to mimic the natural geomorphic process of channel migration and adjustment to an obstruction. The scope of the study included the comparison of selected channel geometry characteristics and bed material particle-size distribution in seven LWD treatment reaches with that of adjacent untreated reaches (unaffected by LWD accumulations) of Locust Creek. A comparison of 1996 and 2015 survey cross sections in treated and untreated reaches and photograph documentation were used to assess channel geomorphic change and the stability of redistributed LWD. The physical characteristics of LWD within jams present in the study reach during 2015-16 also were documented.

Based on the general lack of differences in channel metrics between treated and untreated reaches, it can be concluded that the mechanical redistribution technique has been an effective treatment of extensive LWD jams in Locust Creek. Channel alterations, including aggradation, streamflow piracy, and diversions, have resulted in temporal and spatial changes in the Locust Creek channel that may affect future applications of the redistribution technique in Pershing State Park. The redistribution technique was used to effectively manage LWD in Locust Creek at a potentially lower financial cost and reduced environmental disturbance than the complete removal of LWD.

A comparison of four channel metrics (bankfull crosssectional area, channel width, streamflow capacity, and width-depth ratio) for individual treatment reaches with adjacent untreated reaches indicated no statistically significant difference in most comparisons. Where statistically significant differences in channel metrics were determined between individual reaches, the channel metrics in treatment reaches were significantly less than adjacent untreated reaches in some comparisons, and significantly greater than adjacent untreated reaches in others. Without immediate posttreatment cross sections in treated and untreated reaches for comparison, it is impossible to say with certainty that a lack of significant differences in channel metrics is a result of posttreatment channel adjustment or, conversely, that any significant differences that remain are a result of the treatment of LWD.

Characteristics of LWD in accumulations sampled within the study area in 2015 indicate that most sampled pieces were in the 1-2 foot diameter size class, the 5-16 foot length class, and the advanced decay class. Most of documented LWD pieces were loose and not buried, about 20 percent on average had a root wad attached, and about 6.5 percent on average were sawn logs. Most of sampled material was less than one-half of the bankfull channel width, indicating it was easily transportable, and the advanced decay class of material entering the study area indicated that it was likely sourced from outside of Pershing State Park.

Redistributed LWD associated with treatment seems to be intact in the 1996 treated reaches from direct observation and from inference because there was net channel aggradation between 1996 and 2015 in comparison surveys. The change in channel area resulting from aggradation in time (1996 to 2015) in treated and untreated reaches exceeded the differences in channel characteristics between the treated and untreated channels in 2015 surveys.

\section{Introduction}

The transport, deposition, and sequestration of large woody debris (LWD; defined as logs and branches greater than 0.3 foot [ $\mathrm{ft}]$ in diameter and 5 feet in length) are integral components of forested stream systems including those in northern Missouri (Guyette and others, 2002; Guyette and others, 2008). Benefits of LWD in stream channels are well known and include providing geomorphological control (Abbe and Montgomery, 1996; Downs and Simon, 2001; Frothingham and others, 2001; Rhoads and others, 2003; Cordova and 
others, 2007) and physical habitat for aquatic communities including fish (Angermeier and Karr, 1984; Schlosser, 1991; Crook and Robertson, 1999; Talmage and others, 2002) and invertebrates (Benke and others, 1985; Trotter, 1990; Everett and Ruiz, 1993; Johnson and others, 2003; Hrodey and others, 2008).

Historically, the removal of LWD in stream channels was one of the most common forms of stream habitat modification in the United States (Montgomery and others, 2003). The LWD was removed to increase conveyance, to control bank or bed erosion resulting from deflected streamflows, or to improve navigation. Guidelines for selective removal of LWD formations (International Association of Fish and Wildlife Agencies, 1983; Shields and Nunnally, 1984; Gurnell and others, 1995) have been proposed to reduce possible adverse effects of LWD removal on stream habitat and stability, but the effectiveness of the guidelines as conservation practices has not been thoroughly evaluated. The consensus among researchers is that LWD management protocols should be as minimally disruptive as possible (Angermeier and Karr, 1984; Shields and Nunnally, 1984; Gurnell and others, 1995).

A substantial part of the streams in the United States have been altered through channelization although quantitative estimates differ (National Research Council, 1991). Streams throughout much of northern Missouri have been channelized to increase conveyance and facilitate the removal of standing water and runoff to enhance agricultural land uses. The increased stream slope after channelization increases stream power and results in a sediment transport imbalance. This imbalance commonly results in upstream degradation of the main channel and tributary streams; bank failures along incised reaches, particularly if riparian vegetation cover is sparse; and subsequent infilling of the downstream reaches of the main channel (Parker and Andres, 1976; Simon, 1989). The change in channel dimensions accompanying this response eventually leads to aggradation and channel destabilization within the incised system. Bank failures can result not only in the delivery of large quantities of sediment but also in substantial quantities of LWD. The recovery process after channelization generally takes many decades (Hupp, 1992) and depends on many factors including the extent and location of channelization in the basin, geology, soils, streamflow, and riparian vegetation (Hupp, 1992; Simon and Rinaldi, 2006).

Historically, LWD jams in Locust Creek have been managed using a variety of techniques in lieu of complete removal including manual cutting of in-channel material and partial excavation of LWD (Tom Woodward, Missouri Department of Natural Resources, oral commun., 2014). The most extensive LWD jams, which required permits from the U.S. Army Corps of Engineers for treatment, primarily have been in reaches within Pershing State Park (fig. 1). Treatment was done in association with permitted activities in 1996, 1999, 2002, 2003, 2005, 2008, and 2009 (fig. 2). Section 404 of the Clean Water Act authorizes the U.S. Army Corps of Engineers to issue permits "for the discharge of dredged or fill material into the navigable waters" (U.S. Environmental Protection
Agency, 2016). Fill material is any material placed in a body of water in the United States that has the effect of replacing any part of the water with dry land or changing the bottom elevation. Treatments of extensive LWD jams were done from 1996 to 2009 using a low-impact technique in which LWD was mechanically redistributed to the inside meander of the channel to minimize the alteration of fill material and to minimize disturbance within the park. By redistributing the LWD, the conveyance of the channel is increased and allows for the natural geomorphic process of channel adjustment (Florsheim and others, 2008) to an obstruction that includes channel migration around the jam by means of the erosion of the opposite bank. Treatment consisted of the mechanical redistribution of LWD and accumulated sediments towards an accessible side of the channel preferentially against a naturally aggrading, inside meander for maximum stability. Complete removal of debris would require construction of access roads for haul trucks, corresponding destruction of riparian forests and compaction of soils, greater financial expense than the redistribution technique, and a potential loss of in-channel beneficial functions of LWD. A minimum of 60 percent of the channel was opened and any material placed on top of the bank extended no more than $1 \mathrm{ft}$ above the flood plain. The length of the treated reaches varied from 500 to $4,000 \mathrm{ft}$ (fig. 2). The efficacy of the redistribution technique has not been quantitatively tested to determine if the geometry and conveyance of the treated stream channel is different from untreated reaches with time and if the redistributed LWD was being retained in the channel bank.

The objectives of this study were to (1) determine if channel morphometric and hydraulic characteristics in reaches subjected to mechanical redistribution of LWD (treated) were different from those of adjacent untreated reaches (unaffected by LWD accumulations), (2) document the stability of LWD in selected treated reaches, and (3) quantify physical characteristics of LWD in accumulations in Locust Creek within, and near, Pershing State Park and Fountain Grove Conservation Area.

\section{Purpose and Scope}

The purpose of this report is to summarize an assessment of an in-channel redistribution technique used by the Missouri Department of Natural Resources (MoDNR) and Missouri Department of Conservation (MDC) for the management of LWD in a 9.3-mile (mi) reach of Locust Creek within Pershing State Park and Fountain Grove Conservation Area, Linn County, Missouri (fig. 1). The scope of the study includes the comparison of selected channel characteristics, including channel geometry metrics and bed material particle size, in seven treated reaches and adjacent untreated reaches of Locust Creek. Photograph documentation was used to assess the stability of LWD accumulations in selected treated reaches. The physical characteristics including diameter, length, and decay class of selected LWD in jams in Locust Creek within the study area during 2015-16 were documented. 


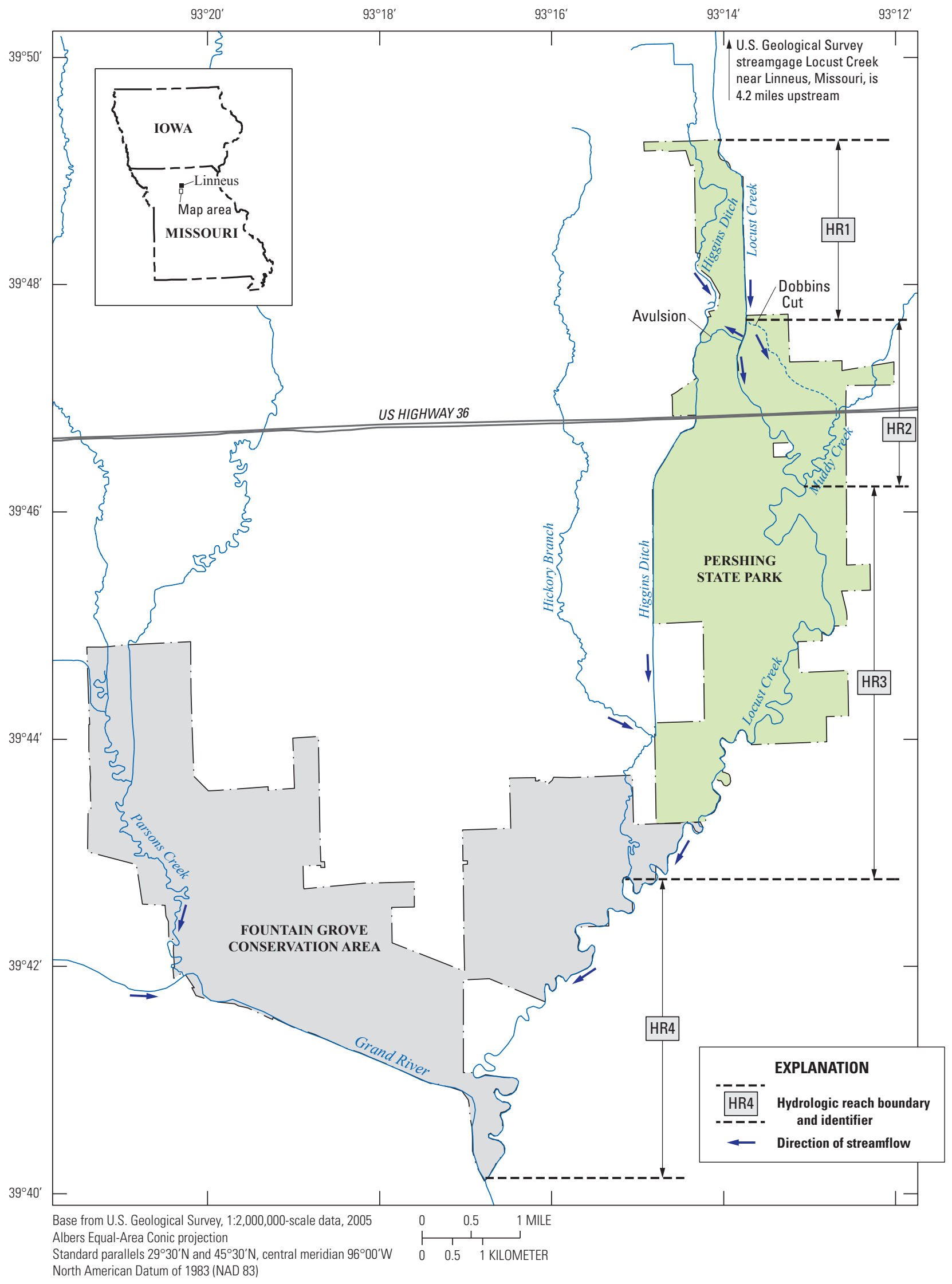

Figure 1. Study area and vicinity. 


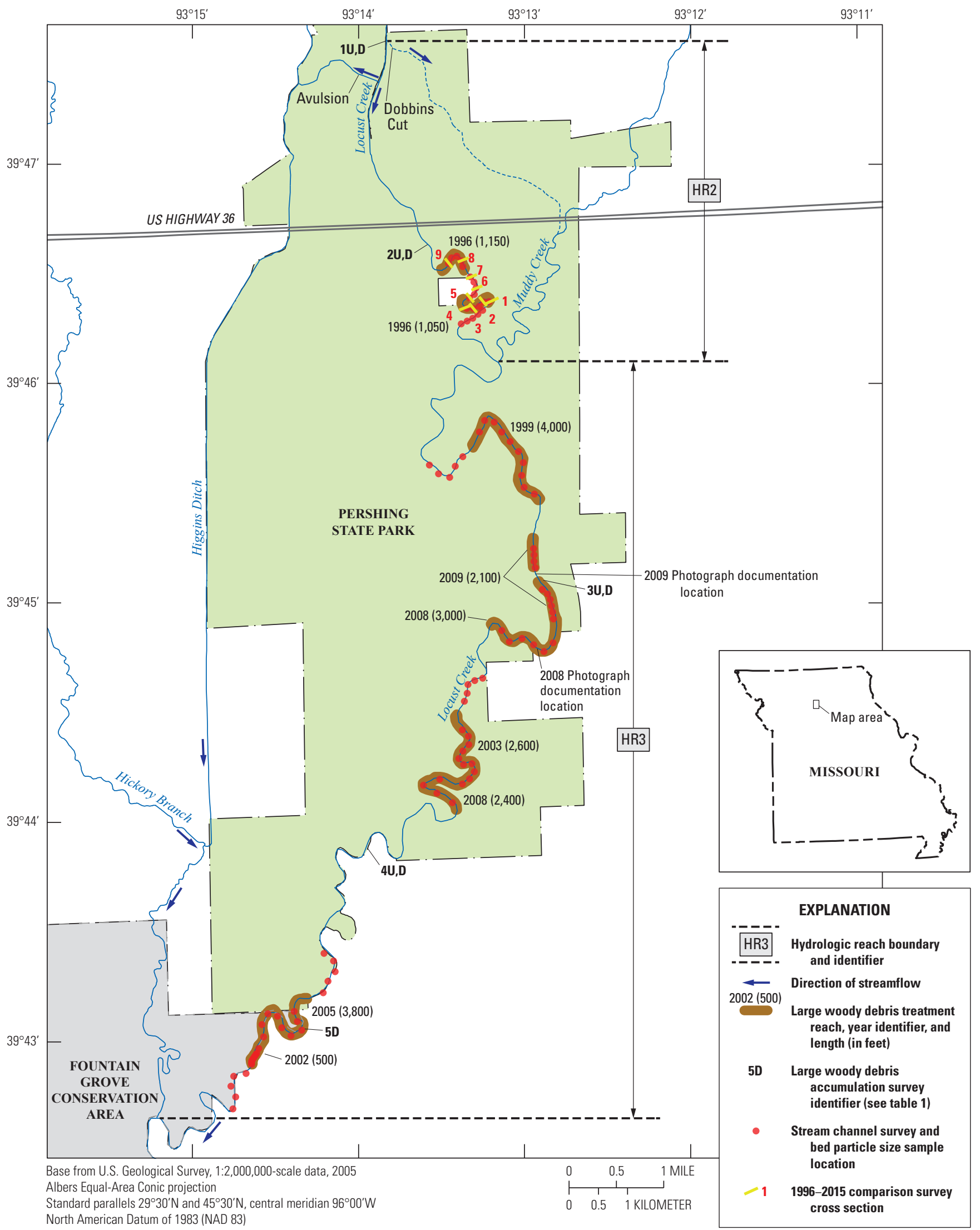

Figure 2. Large woody debris treated reaches, large woody debris accumulation survey locations, and channel survey and channel bed material particle-size sampling locations. 
Results presented in this report are intended to provide some of the information needed by MoDNR and MDC to determine the effectiveness of the mechanical redistribution technique for the treatment of LWD in Locust Creek. Nationally, the methods and results of this study can be used in similar studies assessing the management of LWD in other altered stream systems.

\section{Description of Study Area}

Locust Creek originates in southern Iowa and flows southward about 100 miles through north central Missouri to its junction with the Grand River (fig. 1). The basin covers 648 square miles $\left(\mathrm{mi}^{2}\right)$ within the Glaciated Plains natural division (Thom and Wilson, 1980). Soil associations in the alluvium generally are described as silty clay and silty loam with highly erodible clay loams in the uplands (Benham, 1990). The region is rural with a declining population and no major urban areas. The 2011 land use in the basin (fig. 3) was predominately grassland/pasture (57 percent) followed by forest (19 percent) and cropland (14 percent; Homer and others, 2015). About 2 percent of the basin is in public ownership (Pitchford and Kerns, 1998). The climate in the basin, as in Missouri in general, is continental and marked by strong seasonality; most precipitation falls in spring and early summer. The 1981-2010 average annual precipitation at Linneus, Mo., in the central part of the basin, was 41.6 inches (National Oceanic and Atmospheric Administration, 2017). By the early 1920s, channelization and levee construction, funded by private organizations, were widely implemented in the basin upstream from the present day location of Pershing State Park (Grantham, 1987; fig. 1).

Higgins Ditch (fig. 1), a man-made drainage ditch constructed in the 1940s to the west of Locust Creek was developed to facilitate drainage of Locust Creek overflows through a part of the unchannelized reach (HDR Engineering Inc., 2013). The formation of "pirate channels" connecting the aggraded and "perched" Locust Creek main channel to the lower elevation Higgins Ditch are evident in aerial photographs from the late 1990s (U.S. Geological Survey, 2015). As of 2007, Higgins Ditch captures streamflows for the full range of conditions through a primary avulsion (fig. 1). A second man-made diversion, Dobbins Cut (fig. 1), was created $0.2 \mathrm{mi}$ upstream from the Higgins Ditch avulsion in August 2009 as a series of levee notches allowing a part of Locust Creek high streamflows to flow across low-lying areas to Muddy Creek and return back to Locust Creek 2.4 mi downstream from Dobbins Cut as commingled Dobbins Cut/Muddy Creek streamflow. Before the formation of Dobbins Cut, the Higgins Ditch avulsion was estimated to divert about 80 percent of Locust Creek streamflows from an 11.7 mi reach of the remaining natural channel that passes through Pershing State Park (Great River Associates, Inc., 2011). Since 2009, and the formation of the Dobbins Cut, the 2.4-mi reach of Locust Creek between the Higgins Ditch avulsion and the Dobbins Cut/Muddy Creek return streamflow is the reach most affected by dewatering (Tom Woodward, Missouri Department of Natural Resources, oral commun., 2015).

The $18.6 \mathrm{mi}$ of unchannelized Locust Creek between the northern part of Pershing State Park and the mouth has been aggrading for decades as a result of the deposition of large amounts of sediment from the upstream channelized reaches. The combination of channel alterations and patchy forested stream corridors has resulted in deeply incised and rapidly eroding streambanks. The bank instability, in turn, has resulted in the erosion and transport of large amounts of sediment and LWD into the remnant unchannelized part of Locust Creek in the lower basin. The Locust Creek flood plain has aggraded more than $10 \mathrm{ft}$ in sections of Pershing State Park, since its establishment in 1940, in response to the deposited sediments (Grantham, 1987). In addition to sediment aggradation, numerous and extensive LWD jams have formed in the remnant part of the lower Locust Creek channel. The LWD jams and sediment deposits have reduced the transport efficiency of the natural channel (Alexander, 1997). The reduced conveyance of the unchannelized reach also contributed to the formation of the avulsion and the capturing of Locust Creek streamflows by Higgins Ditch. Deposits of LWD continue to accumulate in the unchannelized reach downstream from the streamflow diversions during high streamflows (most recently in September 2014; Tom Woodward, Missouri Department of Natural Resources, oral commun., 2015) as Locust Creek downstream from the diversions has little stream power to transport the LWD.

\section{Methods}

The approach used in addressing the objectives of this study included characterizing the hydrology of the study reach, which serves as a driving force in the delivery and distribution of LWD and channel form, conducting stream channel topographic surveys to determine possible differences between treated and untreated reaches, and characterization of the physical characteristics of LWD in accumulations. Specific details associated with the characterization of streamflow, channel topography, and stability and characterization of LWD in accumulations are provided in the following sections.

\section{Hydrologic Characterization of Lower Locust Creek}

Remediating LWD accumulations by means of a mechanical redistribution relies on a subsequent natural channel adjustment that depends upon a streamflow-sediment regime that is capable of affecting change in the posttreated channel, that is, a return to untreated (unaffected by LWD accumulations) geometry and hydraulic conditions. Given the rapidly changing Locust Creek channel conditions in response to channelization, diversions, and LWD treatment, rather than determining if the channel has adjusted to pretreated 


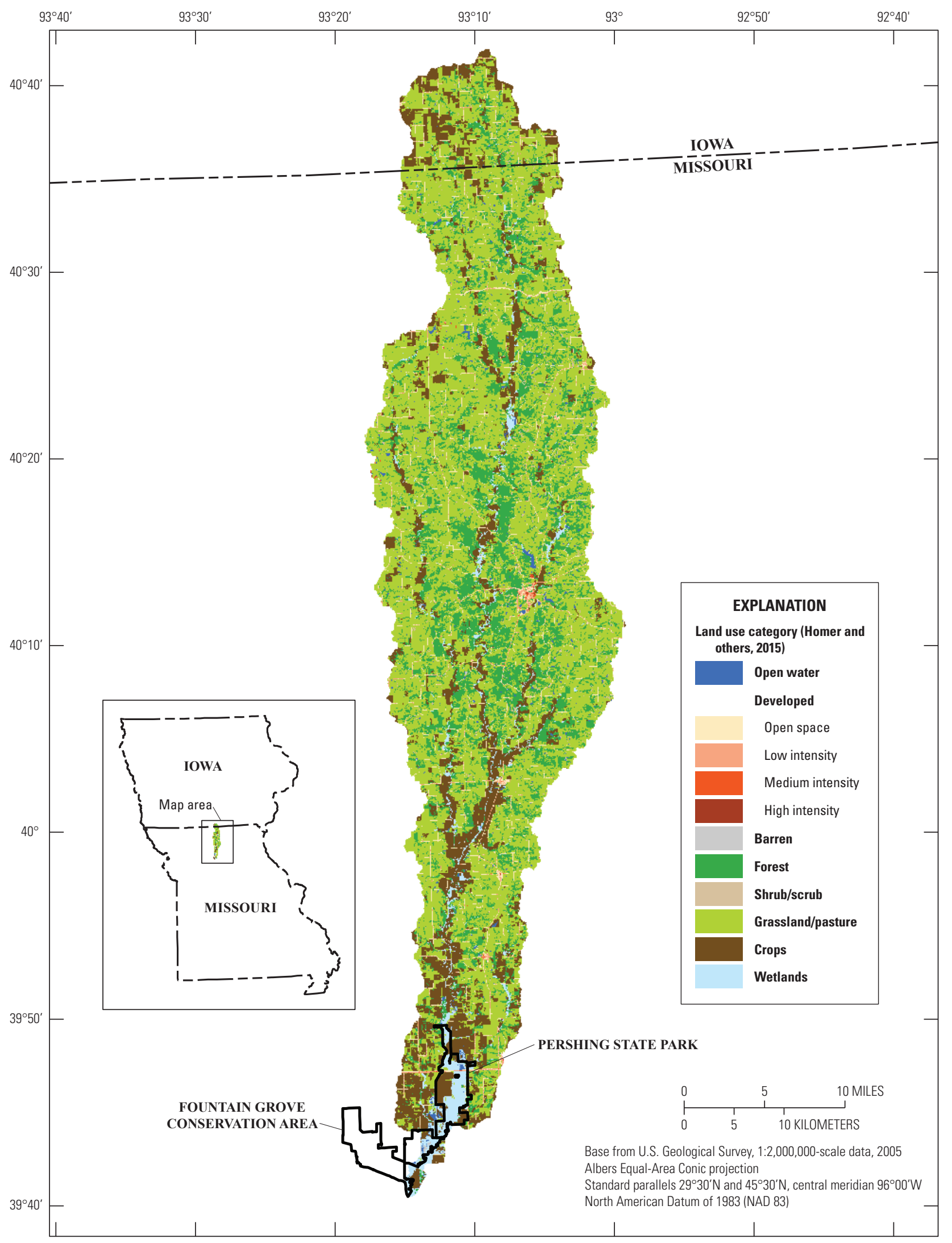

Figure 3. 2011 land use in the Locust Creek Basin (Homer and others, 2015). 
conditions, a more relevant question to ask is if the channel has adjusted to conditions similar to that of adjacent untreated/ unaffected reaches. The primary driver of the adjustment process is streamflow. Locust Creek streamflow is monitored at a U.S. Geological Survey (USGS) streamgage near Linneus, Mo., 4.2 mi upstream from the northern boundary of Pershing State Park. The period of record of streamflow data is 1929-72 and 2001 to present (2017) water years (a water year begins October 1 and ends September 30 and is designated by the calendar year in which the period ends). The 1930 through 2016 annual peak streamflows at the Locust Creek near Linneus streamgage (USGS station number 06901500), obtained from the USGS National Water Information System (NWIS) database (U.S. Geological Survey, 2017), were used to determine possible significant temporal trends using the Kendall's rank correlation coefficient statistic (Kendall, 1975). The proportion of Locust Creek streamflows in the multiple channels downstream from diversions were measured at U.S. Highway 36 bridge openings (fig. 1) in 2015 through 2017 using techniques described in Turnipseed and Sauer, (2010). Streamflows were measured at the Higgins Ditch, Locust Creek, and the combined Dobbins Cut plus Muddy Creek bridge openings for a range of streamflows.

The frequency of bankfull streamflows (the streamflow that happens when the stream fills its channel and any additional discharge will result in the stream overflowing one or both banks) along Locust Creek also was estimated for four differing hydrologic reaches (HRs) within the study area. The use of bankfull flows provides a means of normalizing a hydrologic condition among altered and naturally varying channel conditions. The common bankfull streamflow condition also has been determined to be responsible for most of the geomorphic work in determining channel shape and dimensions (Leopold and others, 1964). The hydrologic reaches within the study area includes a 2-mi channelized reach between the upstream boundary of Pershing State Park and the Dobbins Cut diversion (HR1), a 2.4-mi dewatered reach downstream from the diversions and upstream from the Muddy Creek/Dobbins Cut streamflow return (HR2), a 9.3-mi partially dewatered reach downstream from the Muddy Creek/Dobbins Cut return and upstream from the Higgins Ditch/Hickory Branch return in Fountain Grove Conservation Area (HR3) and a 6.9-mi reach downstream from the Higgins Ditch return to the mouth of Locust Creek (HR4, fig. 1). The annual frequencies of bankfull streamflow with time were estimated for each of the four HRs using streamflow time series from the Locust Creek at Linneus streamgage, channel cross sections and slope obtained from topographic surveys, measured channel and simulated hydraulic conditions in Alexander (1997), the Natural Resources Conservation Service xsecAnalyzer worksheet (version 1.5; Natural Resource Conservation Service, 2016), and estimates of the temporal development of streamflow diversions from Locust Creek to Higgins Ditch and Dobbins Cut (fig. 4). The Locust Creek at Linneus daily mean streamflow (1930-2016 water years) and 15-minute (2000-2016) time series were obtained from the
NWIS (U.S. Geological Survey, 2017). Channel surveys were done using a total station and Differential Global Positioning System (DGPS) instrumentation to determine horizontal position and elevations. The xsecAnalyzer worksheet uses the Manning's uniform flow equation to estimate streamflows at the specified location for incremental channel elevations based on input cross section topographic points, channel slope, and Manning's roughness coefficients ( $n$-values). Active channel $\mathrm{n}$-value estimates ranged from $0.04-0.05$ and vegetated channel and flood plain n-values estimates ranged from 0.07-0.12 based on Barnes (1967). A polynomial curve (Helsel and Hirsch, 2002) was fitted to discrete estimated (estimated assuming a 110 to 150 percent greater streamflow capacity before the effects of aggradation) and computed bankfull (determined from channel surveys and xsecAnalyzer) streamflow capacities for each reach (fig. 5) to estimate the frequency of bankfull streamflows for 1930-2016. The frequency of annual bankfull streamflows in each hydrologic reach was determined by comparing the daily (1930-2016) and 15-minute (2001-2016) streamflows against the corresponding bankfull streamflow threshold as determined using the estimated streamflow corresponding to the physical top of the lowest elevation streambank.

\section{Stream Channel Surveys}

Channel cross sections were surveyed within reaches documented to have undergone LWD redistribution (treated) and in adjacent untreated reaches (unaffected by LWD accumulations) using a total station and DGPS to compare the long-term effects of mechanical redistribution of LWD on channel morphology and channel hydraulic properties. The starting locations of 10 channel cross sections were selected at random for surveying at equal-interval spacing (spacing depended on reach length and ranged from 40 to $370 \mathrm{ft}$ ) within seven documented treated areas (fig. 2). For comparison, an additional 30 channel cross sections were surveyed in untreated reaches distributed upstream and downstream from the treated areas (fig. 2). The starting points of cross sections within untreated reaches also were selected at random and collected at an equal spacing to that of the adjacent treated reach. Selected channel metrics (bankfull cross-sectional area, bankfull top width, bankfull width/depth ratio, bankfull streamflow capacity) of each cross section were computed using the National Resource Conservation Service xsecAnalyzer worksheet (Natural Resources Conservation Service, 2016). Channel metrics were plotted by longitudinal distance from a common reference location and by year of treatment. The overall distributions of selected channel metrics from treated and untreated reaches were statistically compared using a rank sum test (Helsel and Hirsch, 2002) and a significance level of 0.05 . Similarly, the selected channel metrics of the 10 channel cross sections in treated reaches were statistically compared to those computed for the nearest 5 upstream and 5 downstream cross sections in untreated reaches using a rank sum test and 
A. Downstream from Dobbins Cut diversion and upstream from Higgins Ditch avulsion

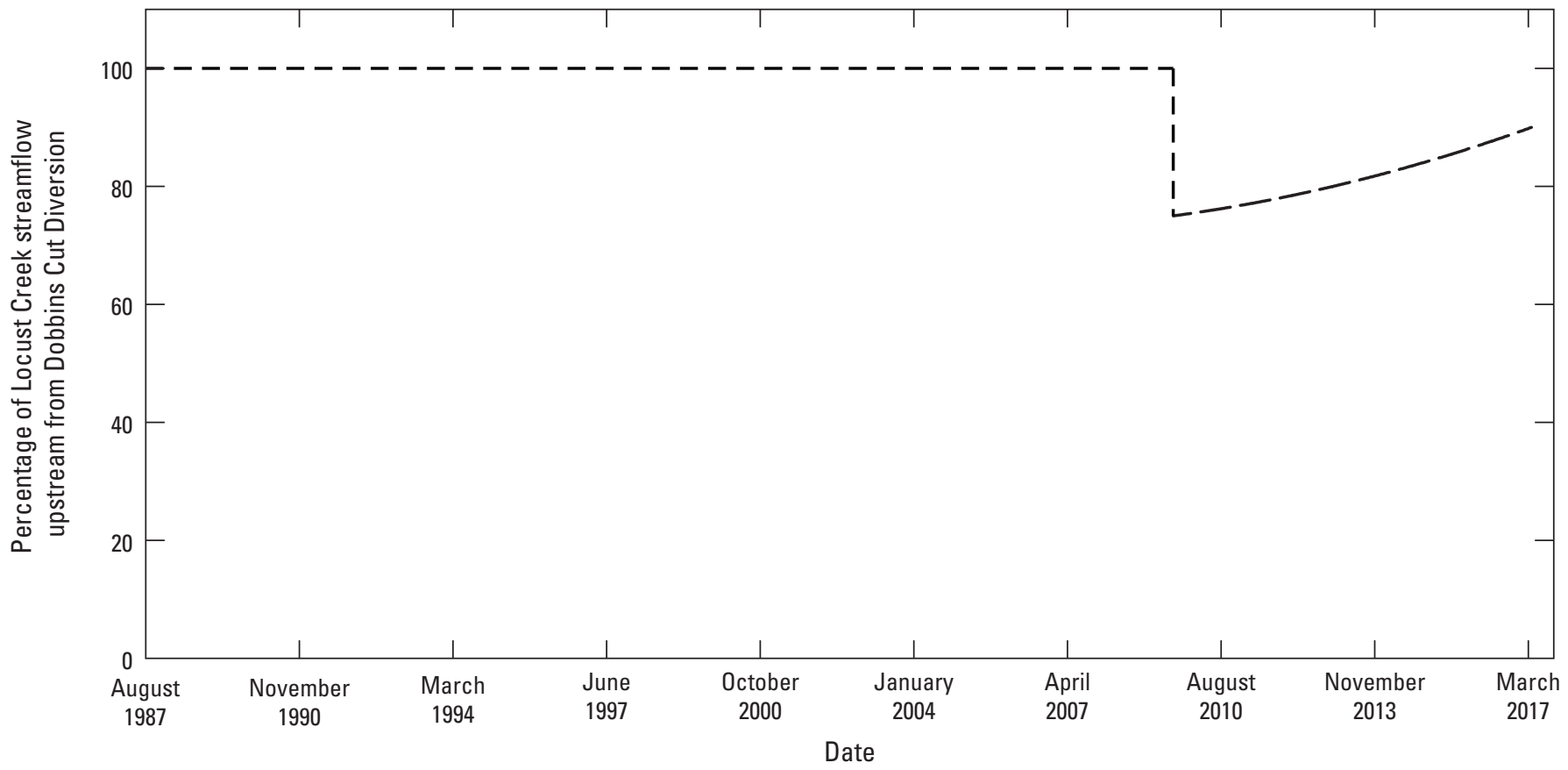

B. Downstream from Higgins Ditch avulsion

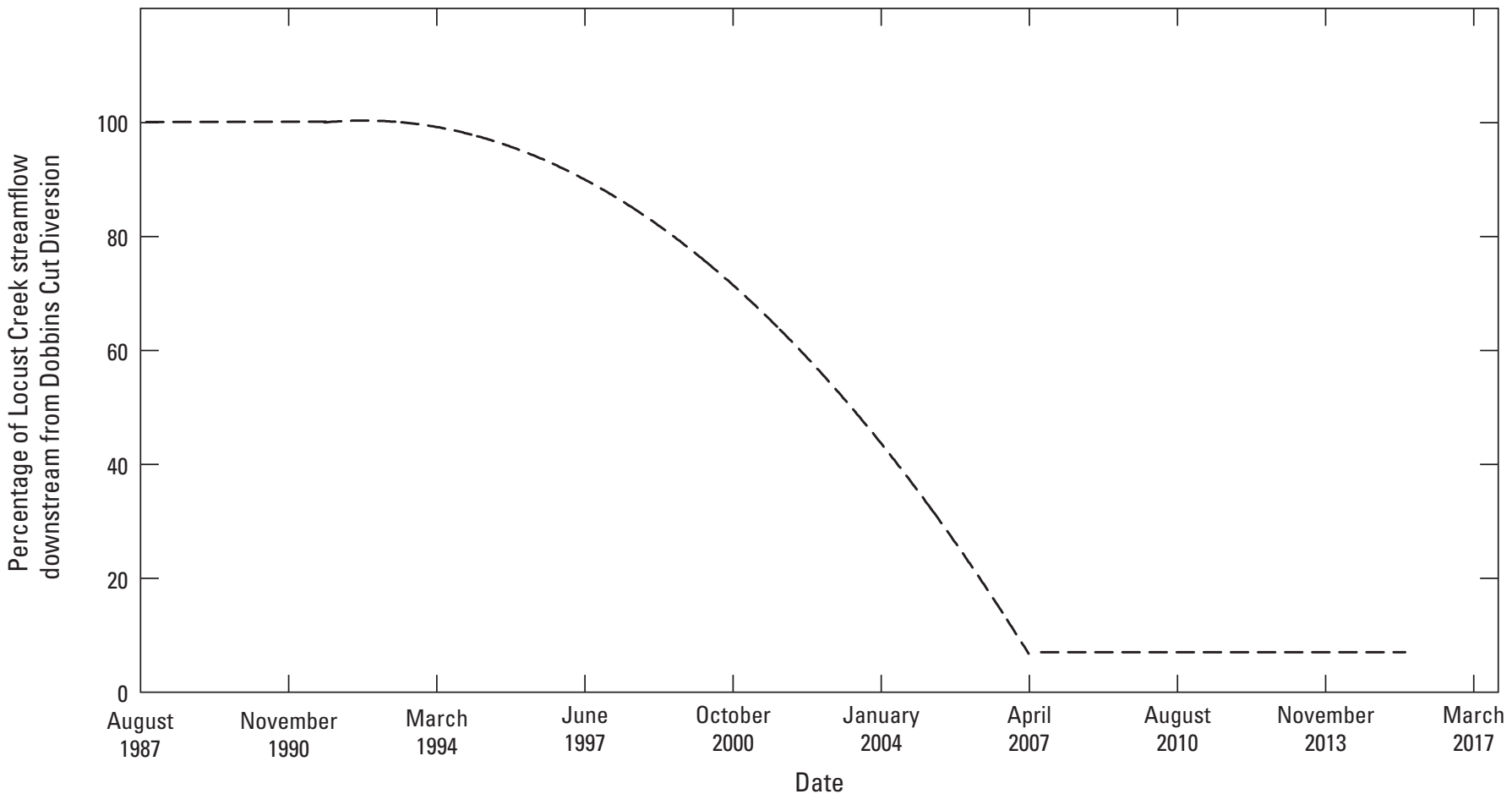

Figure 4. Hypothetical temporal change in Locust Creek streamflow. $A$, Streamflow downstream from Dobbin's Cut diversion. $B$, Streamflow downstream from Higgins Ditch avulsion. 


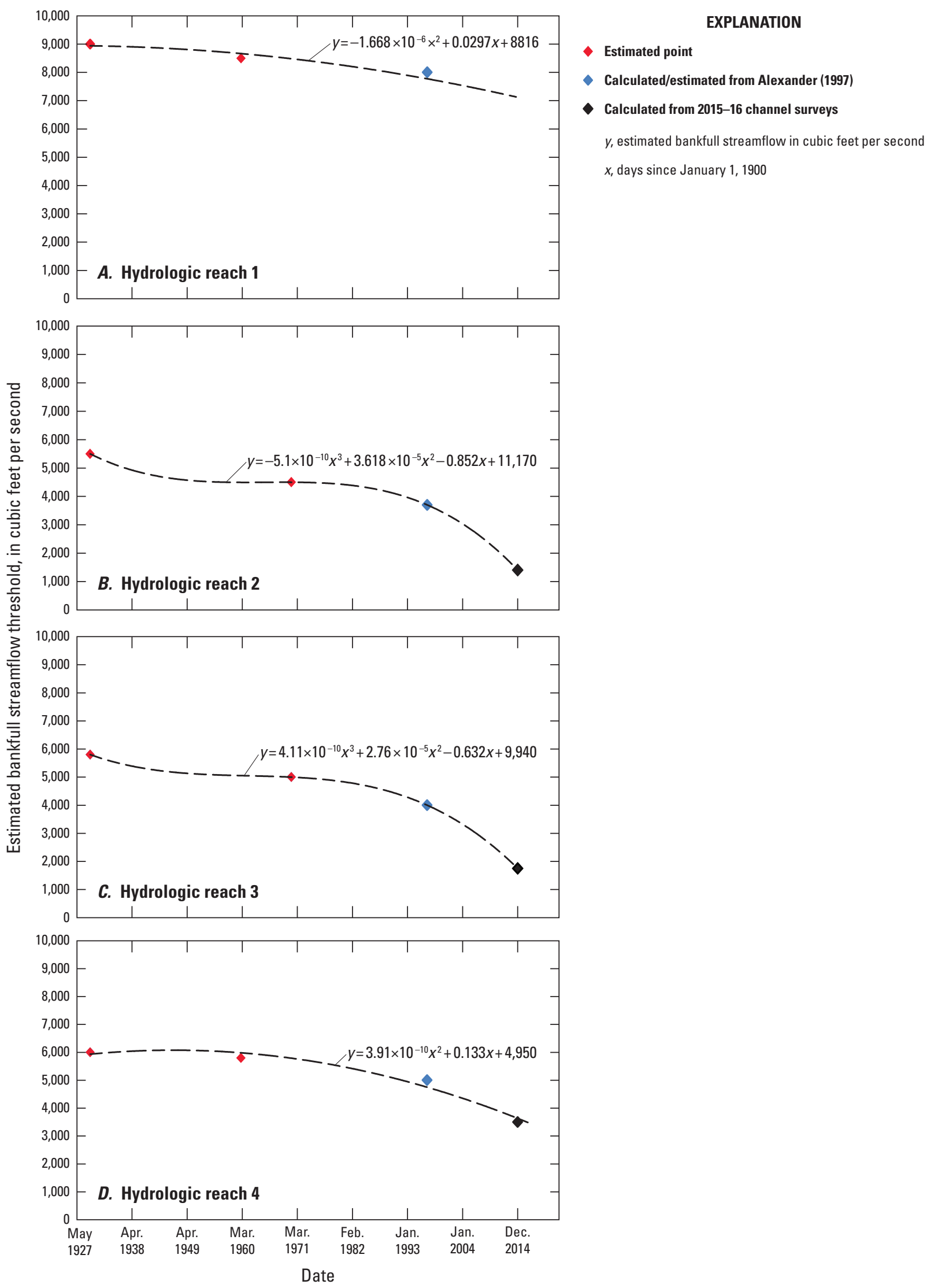

Figure 5. Estimated temporal change in the bankfull streamflow threshold in Locust Creek hydrologic reaches 1-4, 1930-2016 water years. 
significance level of 0.05 . Bed material samples were collected from the top 6 inches of the streambed from three locations (left, center, right) in each surveyed cross section. The three samples were composited and analyzed for six particle-size classes (less than $(<) 2$ millimeters $(\mathrm{mm}),<1 \mathrm{~mm},<0.5 \mathrm{~mm}$, $<0.25 \mathrm{~mm},<0.125 \mathrm{~mm}$, and $<0.063 \mathrm{~mm}$ ) at the USGS sediment laboratory in Rolla, Mo., using the dry-sieve method as described in Guy (1969).

\section{Assessment of Stability of Large Woody Debris}

Channel change and stability after treatment were determined by comparing 1996 cross-section survey data to that of 2015 surveys and by photograph documentation of posttreatment conditions in select treated reaches. Nine channel cross sections surveyed in April 1996 (Alexander, 1997), six in a treated reach and three in an adjacent untreated reach, were compared with cross sections in corresponding locations surveyed in August 2015 (fig. 2). The stability of treated LWD accumulations from 2008 and 2009 treatments also were documented through 2010-2013 photograph documentation of treated reaches done by the MoDNR (Tom Woodward, Missouri Department of Natural Resources, written commun., 2017).

\section{Characterization of Large Woody Debris}

Physical characteristics of LWD in five accumulations within the study area were determined between March 2015 and April 2016. Characteristics documented for each piece included the diameter class $(0.3-<1 \mathrm{ft}, 1-2 \mathrm{ft}, 2-2.6 \mathrm{ft}$, $2.6-3.3 \mathrm{ft}$, and greater than $(>) 3.3 \mathrm{ft})$, length class $(5-16 \mathrm{ft}$,
$>16-50 \mathrm{ft},>50-100 \mathrm{ft}$, and $>100 \mathrm{ft}$ ), decay (Jones and Daniels, 2008; Jones and others, 2010) and position class (table 1), and presence of root wad or saw marks. The listed characteristics were tallied by class for the first 100 pieces of LWD detected in an accumulation with surveys designated as starting from the upstream or downstream extent of the accumulation.

\section{Assessment of In-Channel Large Woody Debris Redistribution Technique}

The results of the analyses of the hydrology, channel topographic surveys, and physical characteristics of LWD in accumulations in Locust Creek were used to assess the effectiveness of a mechanical redistribution technique to manage LWD accumulations in and near Pershing State Park. A discussion of specific information for each of these topics is provided in the following sections.

\section{Hydrology of Lower Locust Creek}

The sum of streamflows was measured at the Highway 36 bridge openings for Locust Creek, Higgins Ditch, and Dobbins Cut combined with Muddy Creek, and ranged from 200 to 10,700 cubic feet per second on several dates in 2015 through 2017 (table 2). The distribution of streamflows through the bridge openings indicated that Higgins Ditch captured from 74 to greater than 99 percent of Locust Creek streamflow depending on the condition. The HR2 reach of the Locust Creek channel conveyed from 0 to about 8 percent of total

Table 1. Large woody debris position and decay class category descriptions.

[>, greater than; \%, percent; cm, centimeters]

\section{Position classes $^{1}$}

$\begin{array}{r}\text { Anchor } \\ \text { Loose/matrix } \\ \text { Buried }\end{array} \quad \begin{aligned} & \text { Log spans most or all of wetted channel and movement is impeded by contact with bank or streambed. } \\ & \text { Log is fully or partly incorporated into the streambed or the sides of the streambank. } \\ & \text { Decay classes }{ }^{1}\end{aligned}$
I $\quad \begin{aligned} & \text { Wood has }>75 \% \text { bark still intact, bark adheres tightly; branches have fine (third order) branchlets; sapwood is sound, and } \\ & \text { log retains structural integrity. }\end{aligned}$
II $\quad \begin{aligned} & \text { Wood has } 25-75 \% \text { bark intact, which, in places, is loosely attached to the bole; first-order branches have a solid connec- } \\ & \text { tion to the bole; wood is solid with evidence of decay on some outer sections of sapwood only. }\end{aligned}$
III $\quad \begin{aligned} & \text { Wood has } 0-25 \% \text { bark present, adhering loosely to the sapwood; first-order branches and branch nubs are present; along } \\ & \text { some parts of the bole, wood shows significant signs of decay to depths of 5-10 cm. }\end{aligned}$
IV Bark is no longer attached; branch nubs only are present; along some parts of the bole, wood is soft, crumbly, or fibrous,
and decay can penetrate nearly through the heartwood.

${ }^{1}$ Position and decay classes from Jones and Daniels (2008) and Jones and others (2010). 
streamflows, and the Dobbins Cut plus Muddy Creek inflows represented from less than 1 to about 19 percent of the total streamflow past U.S. Highway 36 (table 2); therefore, the streamflow in HR3 downstream from the Dobbins Cut plus Muddy Creek inflow can be substantially augmented by these inflows.

Streamflow diversions and channel aggradation have had substantial effects on the frequency of bankfull streamflows in the Locust Creek study reach. The greatest change in Locust Creek hydrology in the 1930-2016 analysis period was in HR2 within Pershing State Park as a result of the development of an avulsion and diversion of streamflow into Higgins Ditch. The pirating of Locust Creek streamflows by Higgins Ditch has been increasing in the last 2 decades (as depicted in fig. 4) as has aggradation in the Locust Creek channel. Of the four defined hydrologic reaches in the study area (fig. 1), the greatest frequency of bankfull streamflows between 1930 and 1972 (fig. 6) was estimated to have happened in HR2. Since 2001, however, and after Locust Creek diversions, the least bankfull streamflows have happened in HR2 (18), and the streamflow likely did not exceed the bankfull threshold in this reach between 2004 and 2016 (fig. 7); therefore, the hydrologic and hydraulic conditions present during the LWD treatment in HR2 in 1996 (fig. 3) have been substantially altered because only 0 to about 8 percent of Locust Creek total streamflow downstream from the diversions is now (2017) carried through this reach depending on time and the magnitude of streamflow (table 2). The bankfull streamflow threshold was exceeded periodically during 2004 to 2016 in the downstream HR3 as a result of Locust Creek streamflows being augmented by Dobbins Cut diversion returns, beginning in 2009, and by Muddy Creek inflows. Channel aggradation and diminishing channel capacity are the primary factors accounting for the increases in the frequency of bankfull streamflows in HR1 and HR4, during the 2001 through 2016 period compared to the 1930-1972 period (fig. 6). Based on 66 annual peak streamflows at the Locust Creek near Linneus streamgage during 1930 to 2016, there was not a statistically significant temporal trend in the magnitude of annual peak streamflows (Kendall's tau $=0.161$, $p=0.06)$.

\section{Comparison of Channel Metrics for Treated and Untreated Reaches}

There were no significant differences in the overall distributions of bankfull channel cross-sectional area $(p=0.09)$, bankfull channel width ( $p=0.39$ ), or bankfull streamflow capacity $(p=0.32)$ among treated and untreated reaches; however, the overall median width-depth ratio in treated reaches (19.6) was significantly $(p=0.02)$ greater than in untreated reaches (17.2; table 3$)$. The significant difference in total width-depth ratio between treated and untreated reaches primarily was attributable to the values from the 2002 treated reach because removing these values results in no significant difference $(p=0.081)$. A comparison of these channel metrics of individual treated reaches with adjacent untreated reaches indicated no significant difference in most (16 of 28) comparisons. Where significant differences in channel metrics were determined between individual reaches, the channel metrics in treated reaches were significantly less than untreated reaches in some cases, and significantly greater than adjacent untreated reaches in others. The greatest number of significant differences (5) between treated and untreated reaches was determined for bankfull channel cross-sectional area, whereas the least were determined for width-depth ratio and bankfull streamflow capacity (2; table 3 ). Channel metrics were more closely correlated with a change in longitudinal channel distance than with years of treatment (figs. 8-9), possibly indicating a basin-scale channel control rather than a local LWD treatment control. There were no substantial differences in bed material particle-size distribution between treated and untreated reaches that would indicate obvious differences in competency and sediment transport characteristics between treated and untreated reaches (fig. 10, table 4).

The bankfull streamflow threshold was exceeded more than 18 times in HR2 since the earliest LWD treatment in 1996 (fig. 6), and 25 times in HR3 since the last treatment in 2009 (and after the creation of the Dobbins Cut diversion and return) indicating substantial opportunity for "geomorphic work" to be done within the channel. Without immediate

Table 2. Distribution of Higgins Ditch, Locust Creek, and Dobbins Cut plus Muddy Creek streamflows through bridge openings at U.S. Highway 36 at Pershing State Park.

$\left[\mathrm{ft}^{3} / \mathrm{s}\right.$, cubic feet per second; $\%$, percent; >, greater than; $<$, less than]

\begin{tabular}{lcccc}
\hline Date & $\begin{array}{c}\text { Total measured } \\
\text { streamflow } \\
\text { (ft } \mathbf{s}^{\text {/s }} \text { ) }\end{array}$ & $\begin{array}{c}\text { Higgins Ditch streamflow } \\
\text { (\% of total) }\end{array}$ & $\begin{array}{c}\text { Locust Creek streamflow } \\
\text { (\% of total) }\end{array}$ & $\begin{array}{c}\text { Combined Dobbins Cut plus } \\
\text { Muddy Creek streamflow } \\
\text { (\% of total) }\end{array}$ \\
\hline $4 / 30 / 2015$ & 200 & $>99$ & 0 & $<1$ \\
$7 / 13 / 2017$ & 3,360 & 84.6 & 6.6 & 9.0 \\
$3 / 30 / 2017$ & 5,810 & 75.8 & 8.37 & 15.8 \\
$7 / 29 / 2015$ & 7,960 & 73.7 & 7.13 & 19.2 \\
$4 / 6 / 2017$ & 10,700 & 90.5 & 4.80 & 4.73 \\
\hline
\end{tabular}



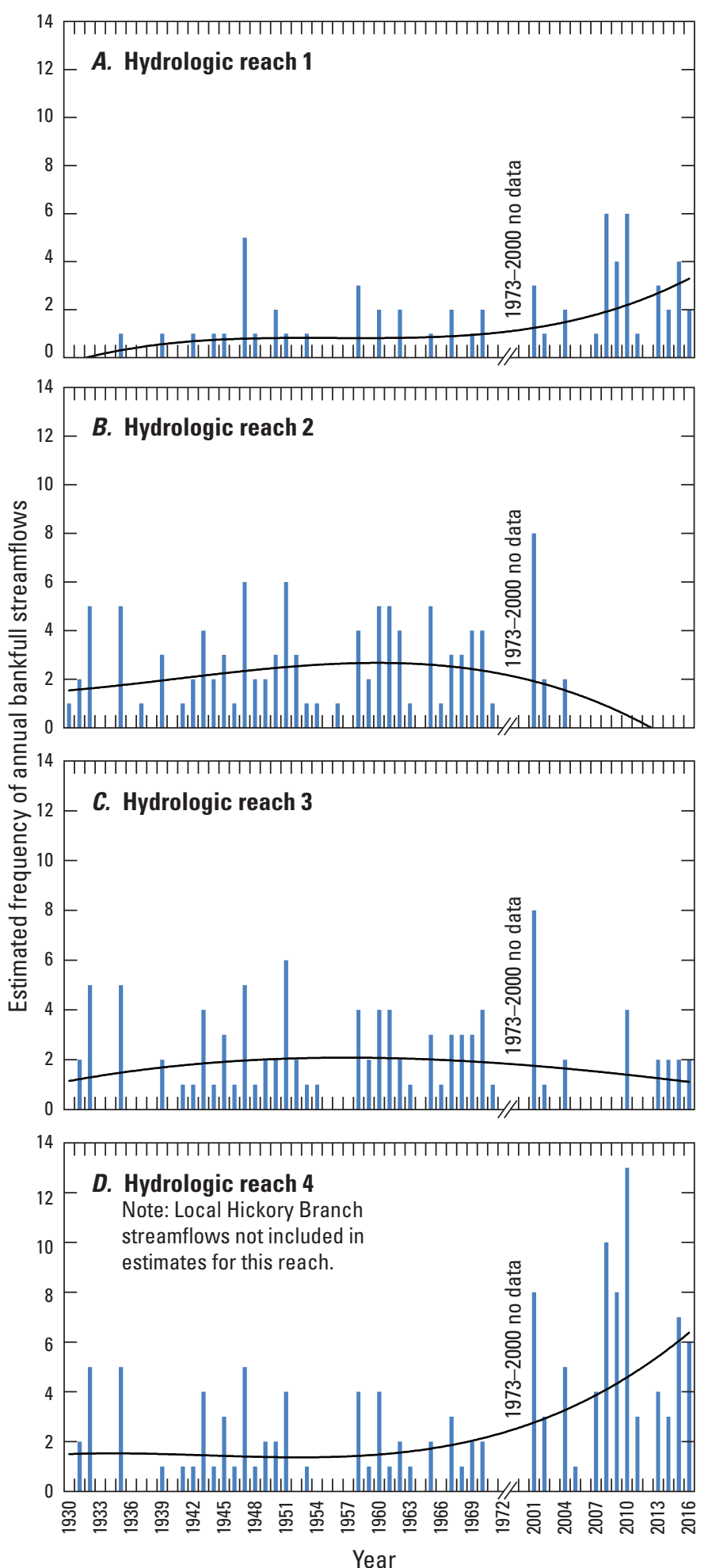

EXPLANATION

Polynomial fit trend line

Figure 6. Frequency of Locust Creek bankfull streamflows by hydrologic reach developed using daily mean streamflow data from the U.S. Geological Survey streamgage Locust Creek near Linneus, Missouri, 1930-2016.
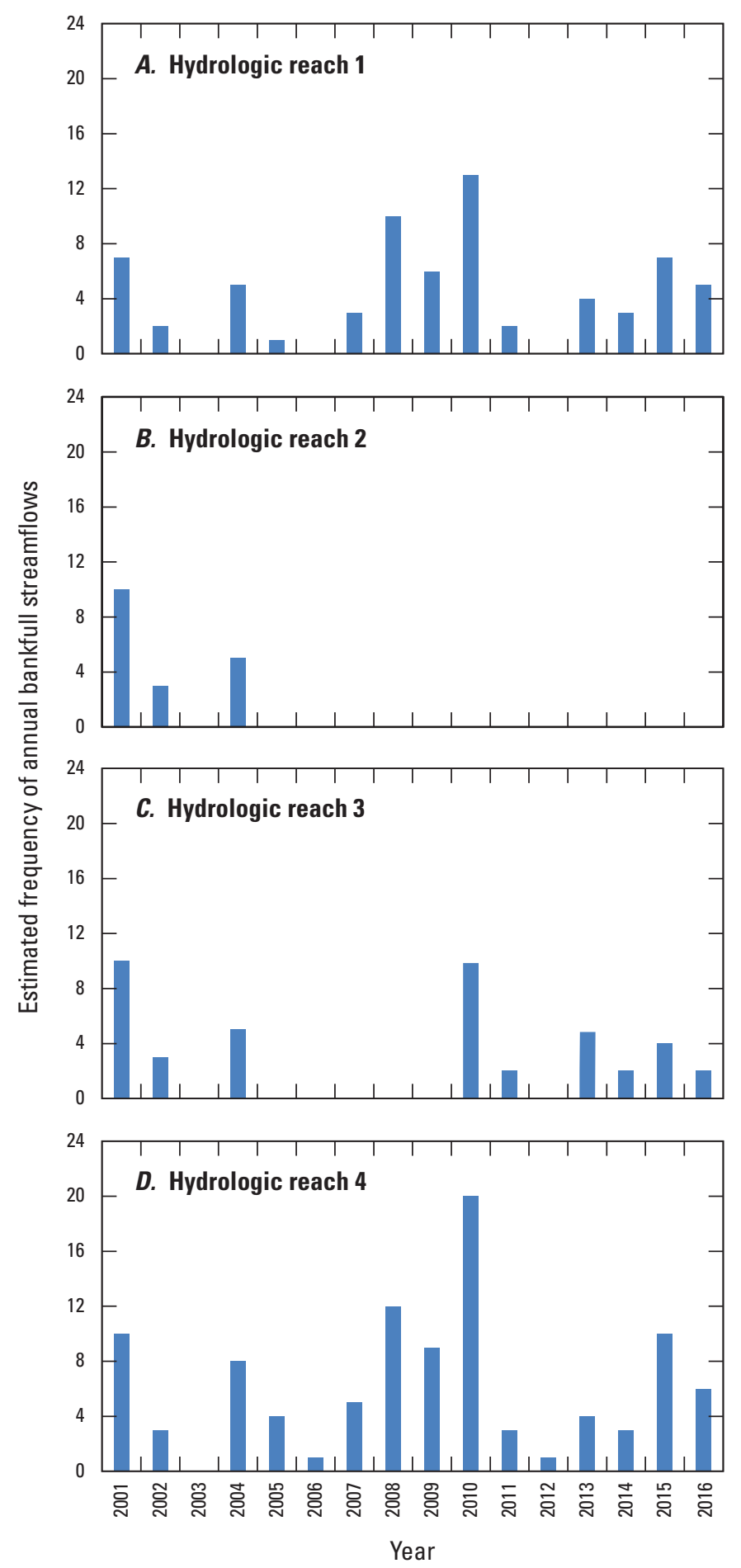

Figure 7. Frequency of Locust Creek bankfull streamflows by hydrologic reach developed using 15-minute streamflow data from the U.S. Geological Survey streamgage Locust Creek near Linneus, Missouri, 2001-2016. 
Table 3. Comparison of bankfull cross-sectional channel area, bankfull channel width, bankfull width-depth ratio, and bankfull streamflow capacity in Locust Creek reaches treated with mechanical redistribution of large woody debris and in untreated reaches.

[ $\mathrm{ft}^{2}$, square feet; $\mathrm{ft} 3 / \mathrm{s}$, cubic feet per second; $\mathrm{p}$-value, statistical probability level; values shaded in gray are statistically significant]

\begin{tabular}{|c|c|c|c|c|c|c|c|c|c|c|c|c|}
\hline \multirow{3}{*}{$\begin{array}{c}\text { Treat- } \\
\text { ment } \\
\text { year }\end{array}$} & \multicolumn{3}{|c|}{$\begin{array}{l}\text { Bankfull channel } \\
\text { cross-sectional area }\end{array}$} & \multicolumn{3}{|c|}{ Bankfull channel width } & \multicolumn{3}{|c|}{ Bankfull width-depth ratio } & \multicolumn{3}{|c|}{ Bankfull streamflow capacity } \\
\hline & \multicolumn{2}{|c|}{ Median $\left(\mathrm{ft}^{2}\right)$} & \multirow{2}{*}{$p$-value } & \multicolumn{2}{|c|}{ Median (feet) } & \multirow{2}{*}{$p$-value } & \multicolumn{2}{|c|}{ Median (unitless) } & \multirow{2}{*}{$p$-value } & \multicolumn{2}{|c|}{ Median $\left(f^{3} / s\right)$} & \multirow{2}{*}{$p$-value } \\
\hline & Treated & Untreated & & Treated & Untreated & & Treated & Untreated & & Treated & Untreated & \\
\hline All & 623 & 671 & 0.094 & 109 & 107 & 0.393 & 19.6 & 17.2 & 0.022 & 1,470 & 1,500 & 0.319 \\
\hline 1996 & 594 & 633 & 0.166 & 106 & 118 & 0.218 & 20.0 & 21.6 & 0.579 & 1,330 & 1,350 & 0.631 \\
\hline 1999 & 577 & 656 & 0.007 & 109 & 107 & 0.796 & 19.0 & 17.7 & 0.739 & 1,320 & 1,460 & 0.007 \\
\hline 2002 & 1349 & 805 & 0.002 & 228 & 104 & $<0.001$ & 37.6 & 13.0 & $<0.001$ & 2,310 & 2,370 & 0.481 \\
\hline 2003 & 638 & 728 & 0.023 & 106 & 104 & 0.971 & 17.3 & 16.2 & 0.280 & 1,310 & 1,820 & 0.012 \\
\hline 2005 & 902 & 805 & 0.166 & 137 & 104 & $<0.001$ & 21.7 & 13.0 & 0.001 & 2,130 & 2,370 & 0.075 \\
\hline 2008 & 591 & 656 & 0.036 & 104 & 107 & 0.684 & 18.9 & 17.7 & 0.800 & 1,400 & 1,460 & 0.739 \\
\hline 2009 & 547 & 656 & 0.001 & 98 & 107 & 0.043 & 18.3 & 17.7 & 0.580 & 1,458 & 1,460 & 0.971 \\
\hline
\end{tabular}

posttreatment cross sections in treated and untreated reaches for comparison, it is impossible to say with certainty that the lack of significant differences in channel metrics is a result of channel adjustment, or conversely, that any significant differences that remain are a result of treatment. What is known is that before treatment, the treated reaches contained LWD jams; the LWD was mechanically redistributed to reopen the channel; and after 18 to 25 bankfull streamflow conditions, in most cases, the selected channel metrics of treated reaches were not significantly different from those of untreated reaches.

\section{Channel Change and Large Woody Debris Stability after Treatment}

Six cross sections that were surveyed in 1996 before LWD treatment and three cross sections surveyed in 1996 in an untreated reach were compared with 2015 surveys at the same locations (fig. 2, table 5, fig. 11). Redistributed LWD associated with treatment seems to be intact in the 1996 treated reaches as the channel changes indicate the 1996 LWD treatment reach underwent net aggradation between the 1996 and 2015 surveys; furthermore, the change in channel cross-sectional area resulting from aggradation exceeded net differences resulting from LWD treatment (table 5). The net aggradation provided stability in sequestered LWD, but also resulted in a reduction in cross-sectional area, channel slope, and bankfull streamflow capacity (table 5). This was true of the treated and untreated sections of this reach. Differences among cross-sectional area, slope, and bankfull streamflow capacity between treated and untreated reaches within a given year (1996 or 2015) were substantially less than the differences between years (table 5).
Photographs taken annually between 2010 and 2013 after treatment in the 2008 and 2009 treatment reaches also document the stability of LWD in these reaches (figs. 12-13). Several factors can affect the stability of redistributed LWD material including streamflow; size, orientation, and placement location (inside or outside the meander) of LWD; composition of sediments incorporated into the redistributed material; and the timing and composition of associated reestablished vegetation. The specific factors accounting for the stability of the redistributed LWD were not determined in this study; nevertheless, there was little apparent change in the redistributed LWD at these locations along with substantial revegetation on the redistributed material.

\section{Physical Characteristics of Large Woody Debris}

Characteristics of LWD jams sampled within the study area in 2015-16 indicated that most sampled LWD pieces were in the 1-2 ft diameter size class (average 63 percent), the 5-16 ft length class (average 75 percent), and decay class III (average 63 percent; table 6). In addition, most documented LWD pieces were loose and not buried (average 90 percent), about 20 percent on average had a root wad attached, and about 6.5 percent on average were sawn logs. Temporal variability in the diameter size class of LWD in the most upstream accumulation was evident because the $0.3-1 \mathrm{ft}$ diameter size class was not represented in the April 2015 survey but represented most LWD sampled in the October 2015 survey after an influx of material into the upstream end of the accumulation during spring and summer high streamflows.

Characteristics of LWD in accumulations near the upstream border of Pershing State Park indicate most LWD is easily transported and likely sourced from outside the park 

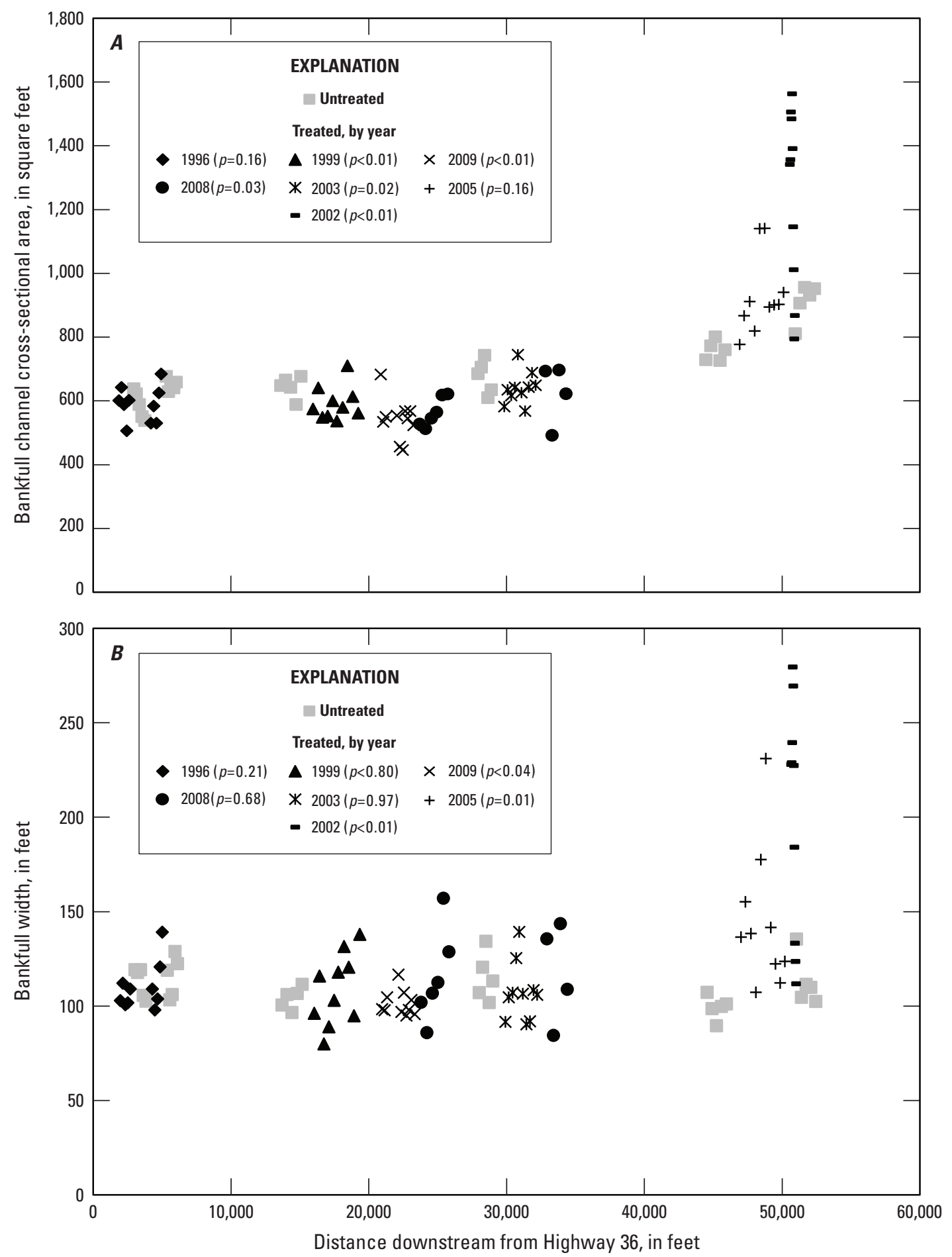

Figure 8. A, distribution of Locust Creek bankfull channel cross-sectional area; $B$, bankfull width; $C$, bankfull width-depth ratio; and $D$, bankfull streamflow capacity for treated and untreated reaches by longitudinal channel distance.

as material in accumulations was small (less than one-half of bankfull channel width) and within decay class III or IV. The decay class indicates that the material has been in the system long enough, or traveled long enough, to have lost all or most bark and decay of heartwood is evident. On average,
20 percent of LWD pieces had an attached root wad indicating the likely source was from streambank failure. Most LWD, therefore, was removed branches or trunk fragments. Aerial surveys in the upstream parts of the basin indicate a continued and pervasive sourcing of LWD to the system through 

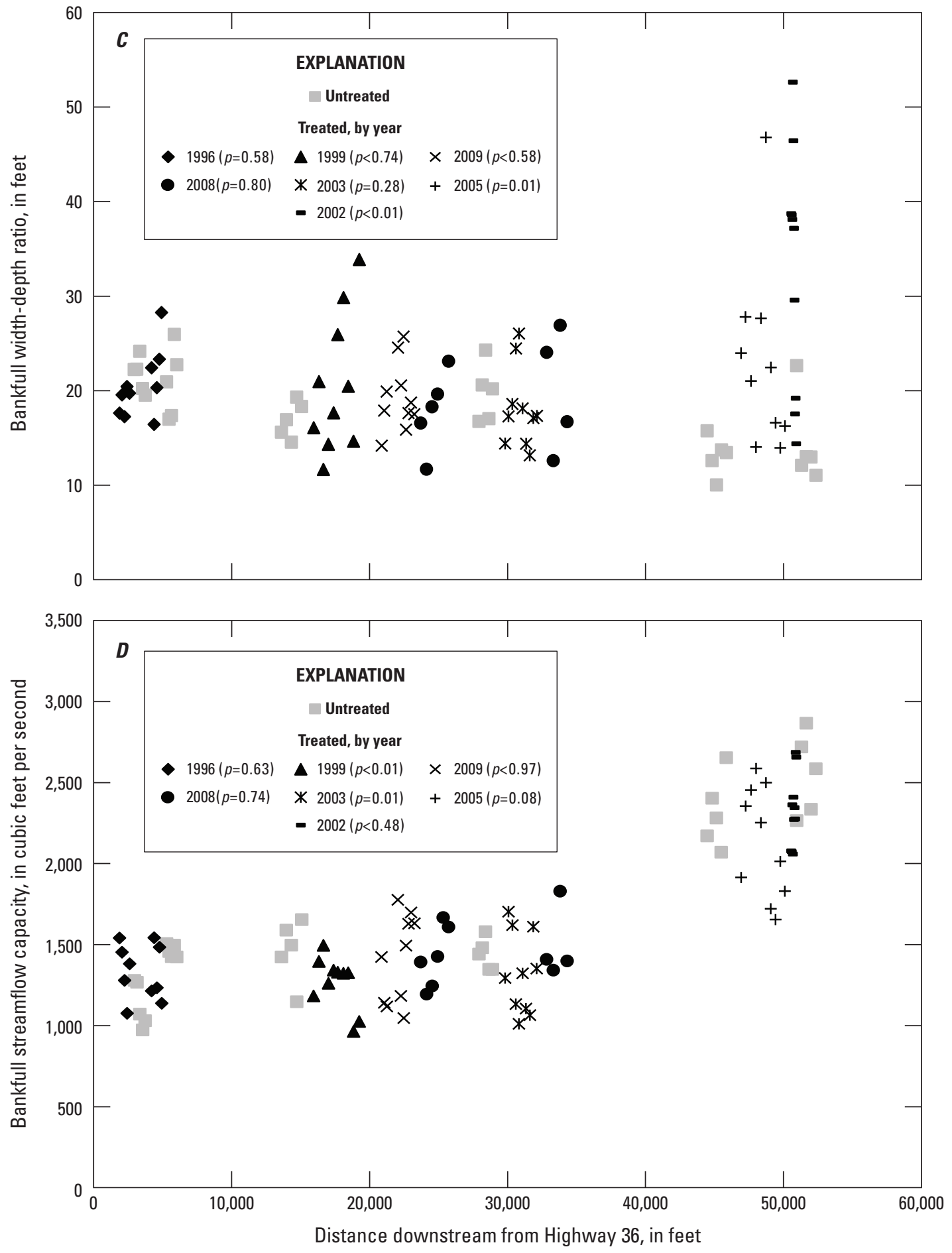

Figure 8. $\quad A$, distribution of Locust Creek bankfull channel cross-sectional area; $B$, bankfull width; $C$, bankfull width-depth ratio; and $D$, bankfull streamflow capacity for treated and untreated reaches by longitudinal channel distance.-Continued

numerous areas of bank instability (Tom Woodward, Missouri Department of Natural Resources, oral commun., 2016).

Factors that can affect the mobility of LWD in the stream channel include streamflow characteristics, length of LWD relative to the channel width, root wads, and bank stability
(Bilby and Ward, 1991; Martin and Benda, 2001). When the ratio of the length of LWD pieces to channel width is $<0.5$, the stream generally controls the distribution of LWD; therefore, in natural systems the density of LWD jams will decrease as channel size increases in a downstream direction (Sedell and 

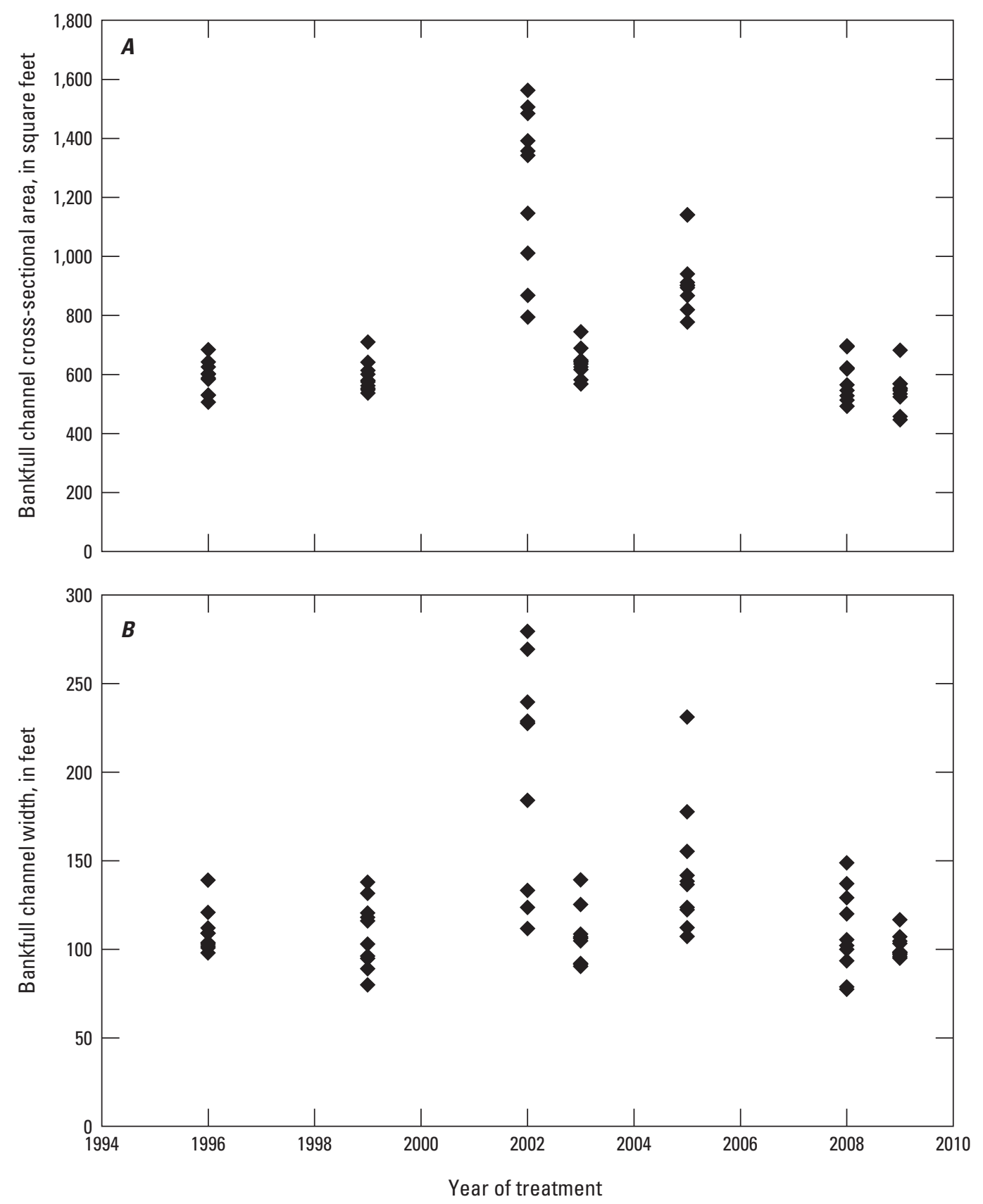

Figure 9. Distribution of $A$, Locust Creek bankfull channel cross-sectional area; $B$, bankfull width; $C$, bankfull width-depth ratio; and $D$, bankfull streamflow capacity by year of large woody debris treatment.

others, 1988). In the highly altered Locust Creek Basin, the effects of channelization and land-use changes, and the resulting bank instability, have resulted in a likely increase in the delivery of LWD compared with the prechannelized system. Concurrently, sediment deposition and streamflow diversions have resulted in a substantial reduction in stream power and capacity to transport material through the downstream unchannelized part of Locust Creek. The altered system also is highly dynamic and, currently (2017), the reduced streamflow and stream power downstream from the diversions, combined with the recent (2014) formation of an LWD accumulation at the site of the diversions, substantially limits the transport of LWD into Pershing State Park. 

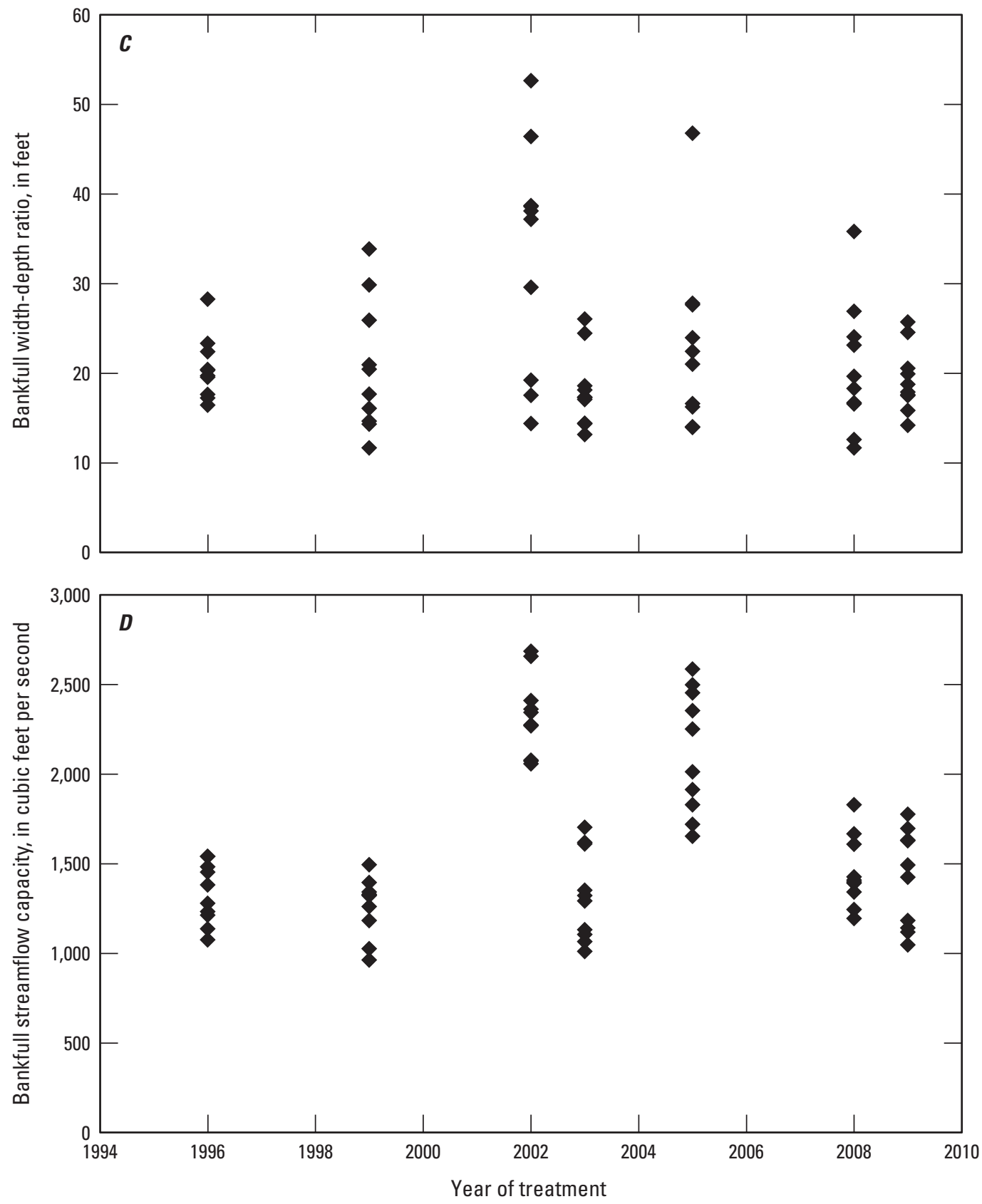

Figure 9. Distribution of $A$, Locust Creek bankfull channel cross-sectional area; $B$, bankfull width; $C$, bankfull width-depth ratio; and $D$, bankfull streamflow capacity by year of large woody debris treatment.-Continued 


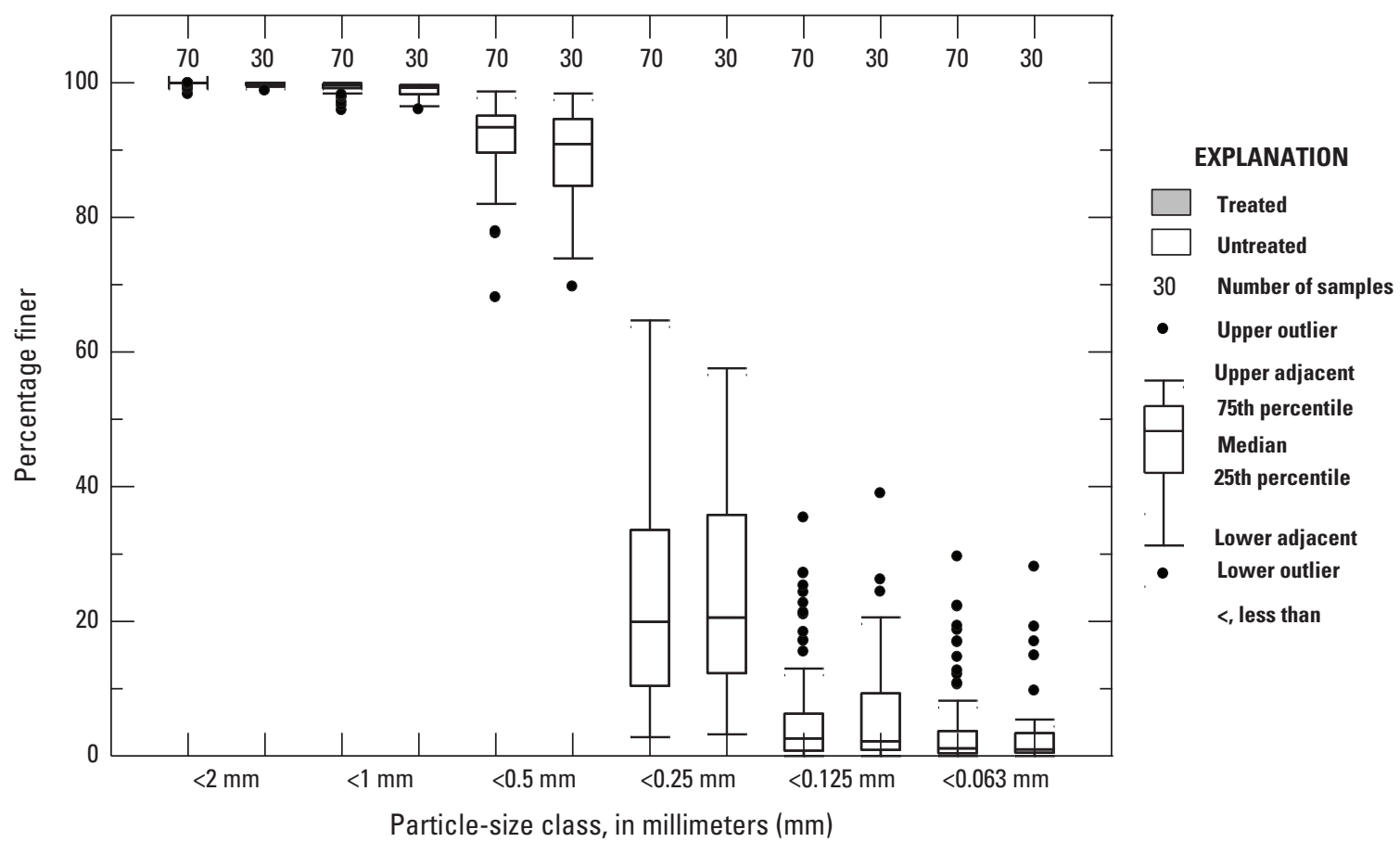

Figure 10. Distribution of particle-size classes of Locust Creek bed material samples from reaches with redistribution of large woody debris (treated) and from untreated reaches.

Table 5. Comparison of selected channel characteristics from 1996 and 2015 cross section surveys in treated and untreated reaches. [ $\mathrm{ft}^{2}$, square feet; $\mathrm{ft} / \mathrm{ft}$ foot per foot; $\mathrm{ft}^{3} / \mathrm{s}$, cubic feet per second]

\begin{tabular}{|c|c|c|c|c|c|c|c|c|c|}
\hline \multirow[b]{2}{*}{ Survey year } & \multicolumn{3}{|c|}{ Mean cross-sectional area } & \multicolumn{3}{|c|}{ Mean channel slope } & \multicolumn{3}{|c|}{ Mean bankfull streamflow } \\
\hline & $\begin{array}{c}\text { Treated } \\
\left(\mathrm{ft}^{2}\right)\end{array}$ & $\begin{array}{c}\text { Untreated } \\
\left(\mathrm{ft}^{2}\right)\end{array}$ & $\begin{array}{c}\text { Difference } \\
\text { (percent) }\end{array}$ & $\begin{array}{c}\text { Treated } \\
(\mathrm{ft} / \mathrm{ft})\end{array}$ & $\begin{array}{c}\text { Untreated } \\
(\mathrm{ft} / \mathrm{ft})\end{array}$ & $\begin{array}{c}\text { Difference } \\
\text { (percent) }\end{array}$ & $\begin{array}{c}\text { Treated } \\
\left(\mathrm{ft}^{3} / \mathbf{s}\right)\end{array}$ & $\begin{array}{l}\text { Untreated } \\
\left(\mathrm{ft}^{3} / \mathrm{s}\right)\end{array}$ & $\begin{array}{c}\text { Difference } \\
\text { (percent) }\end{array}$ \\
\hline 1996 & 684 & 662 & -3.2 & 0.00311 & 0.00256 & -17.7 & 3,776 & 3,087 & -18.3 \\
\hline 2015 & 579 & 588 & 1.5 & 0.00068 & 0.00062 & -8.8 & 1,302 & 1,127 & -13.5 \\
\hline $\begin{array}{l}\text { 1996-2015 } \\
\text { percent change }\end{array}$ & -15.3 & -11.2 & & -78.1 & -75.8 & & -65.5 & -63.5 & \\
\hline
\end{tabular}



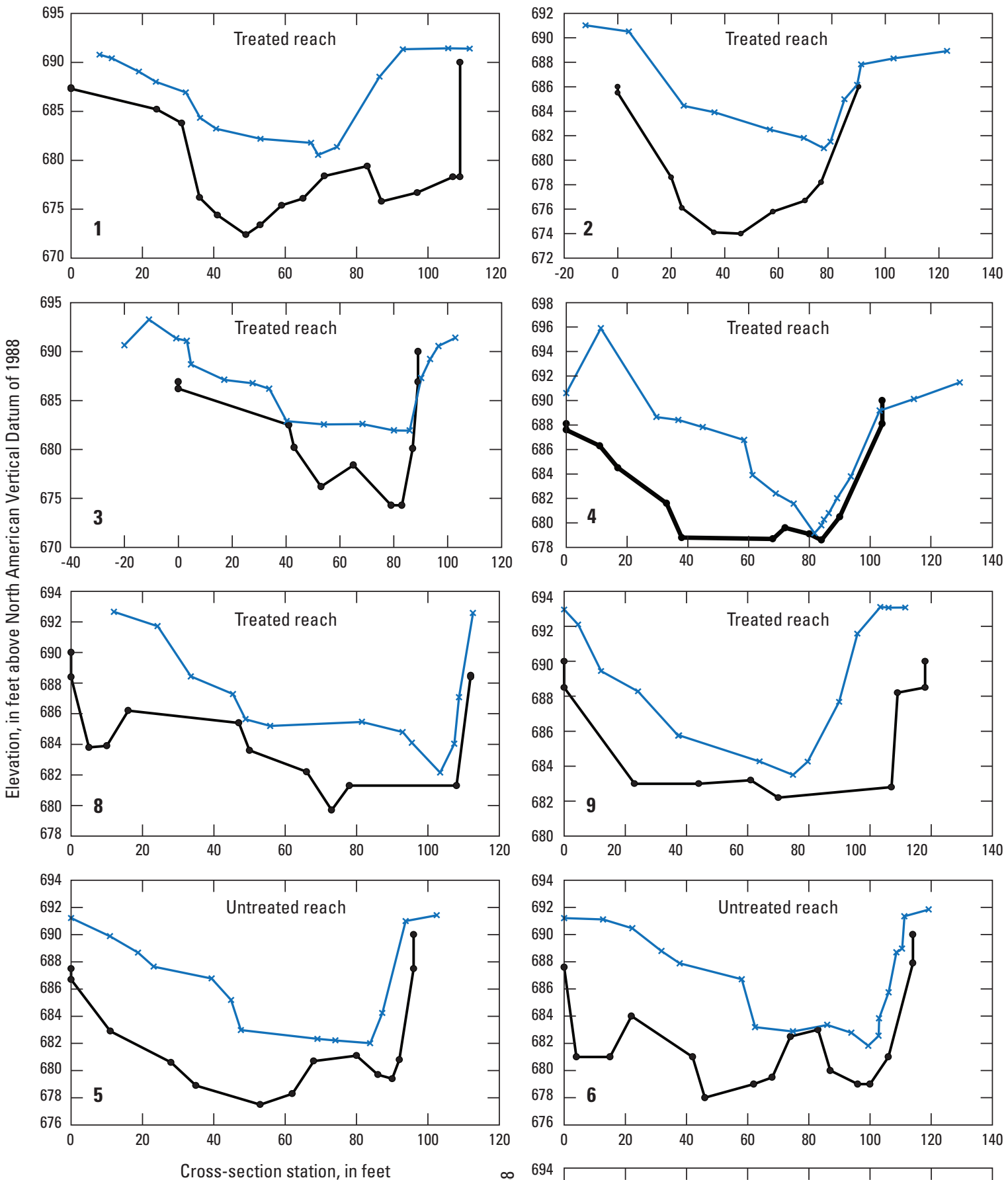

EXPLANATION

- April 1996

April-September 2015

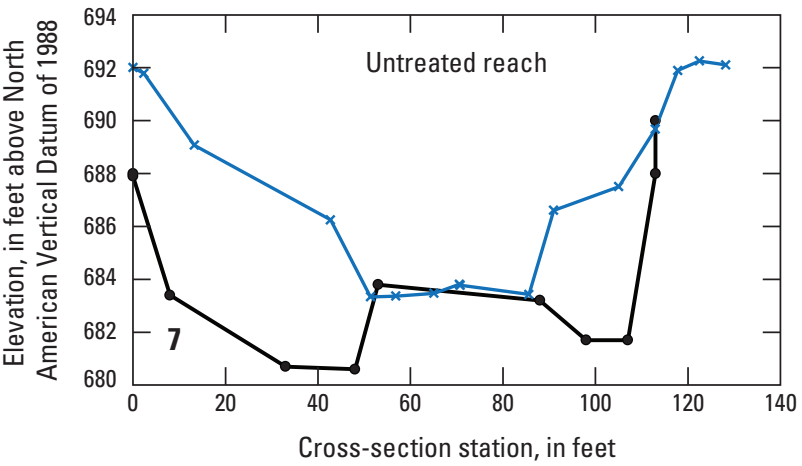

Figure 11. Comparison of selected channel cross sections surveyed in 1996 and 2015 in treated and untreated reaches of Locust Creek. 


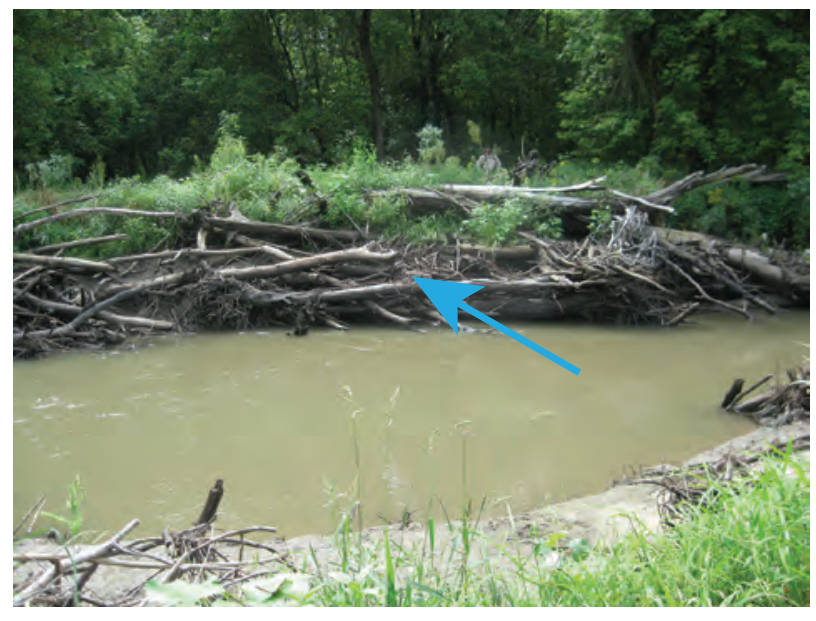

Year 1, 2010, "As much material as possible was incorporated into the bank. The excess, which was mostly the larger and heavier material, was placed on top. Stable bank material locked in place." (10 bankfull streamflows in 2010 water year, 10 cumulative).

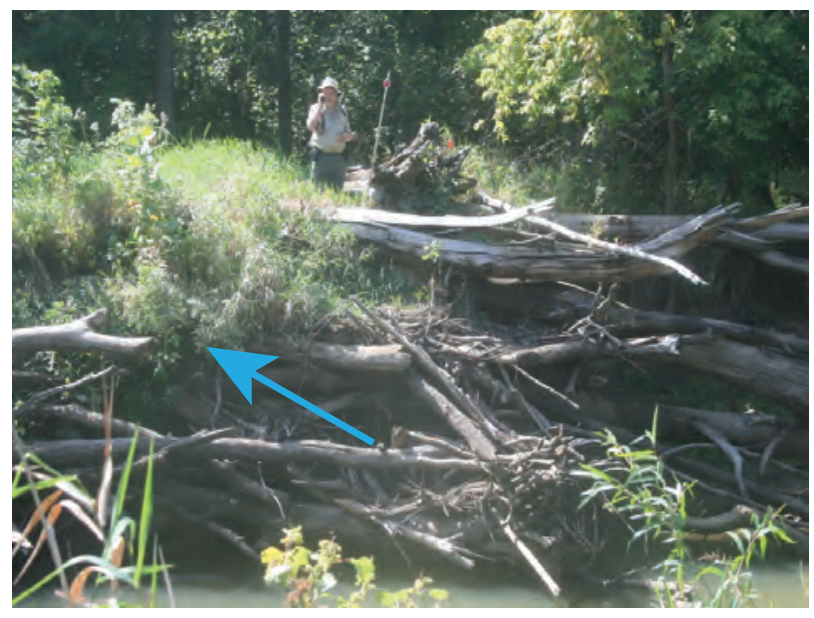

Year 3, 2012, "Lost 1 foot of bank material at top of bank. Large woody debris still in place." (0 bankfull streamflows in 2012 water year, 12 cumulative).

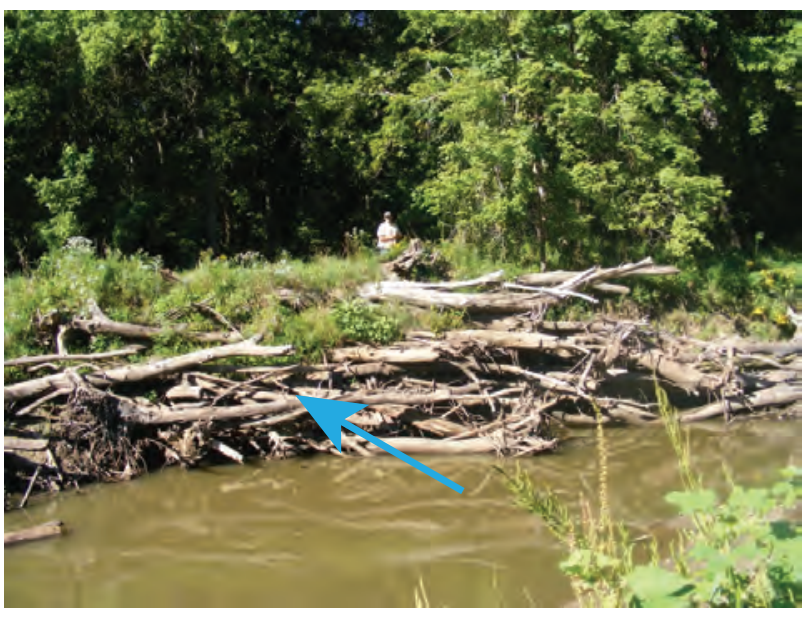

Year 2, 2011, "Sediment in and around the large woody debris is eroding, but the material is still stable." ( 2 bankfull streamflows in 2011 water year, 12 cumulative).

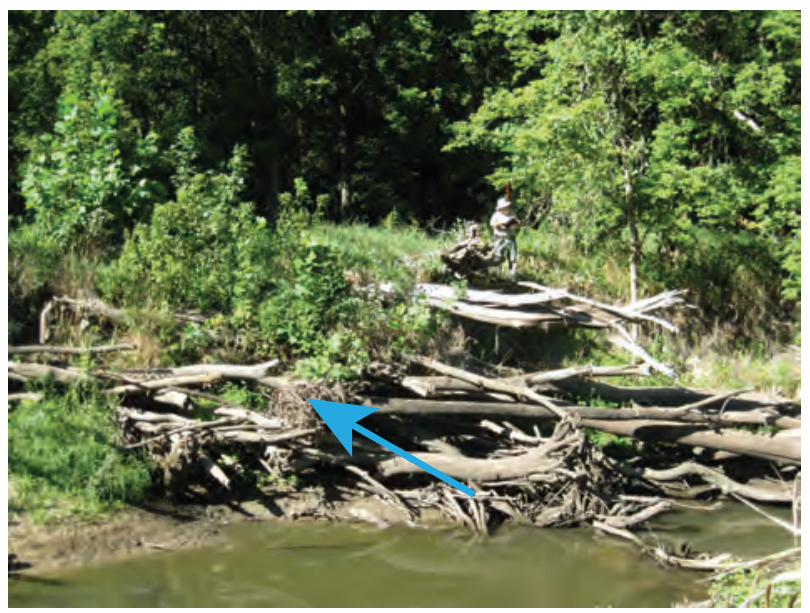

Year 4, 2013, “No change, bank and large woody debris stable. Substantial woody vegetation established on large woody debris." (5 bankfull streamflows in 2013 water year, 17 cumulative).

Figure 12. Photographs and field notes documenting the status of redistributed large woody debris in the Locust Creek 2008 treatment reach during $2010-13$. 


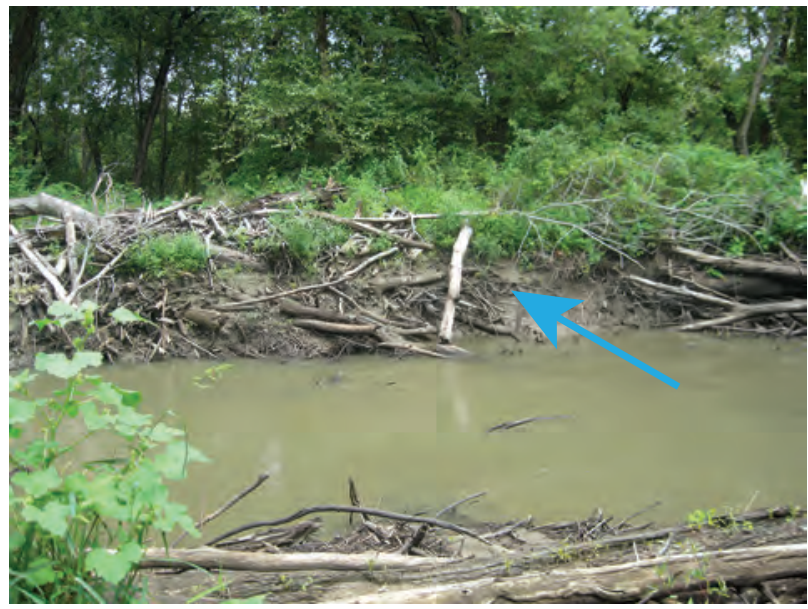

Year 1, 2010, "Left decending bank, material pulled to this side." (10 estimated bankfull streamflows in 2010 water year, 10 cumulative).

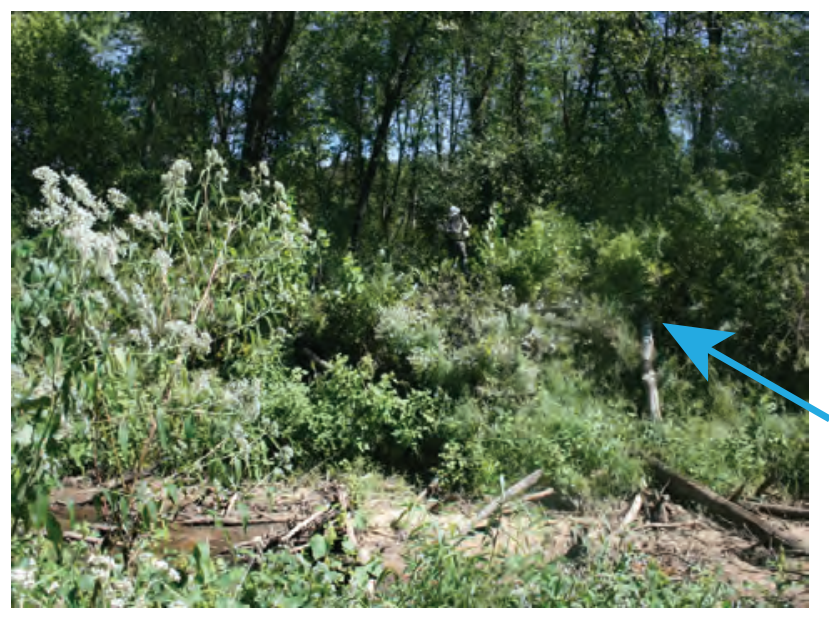

Year 3, 2012, "No changes to bank, sediment at toe/low water, vegetation growth." (0 estimated bankfull streamflows in 2012 water year, 12 cumulative).

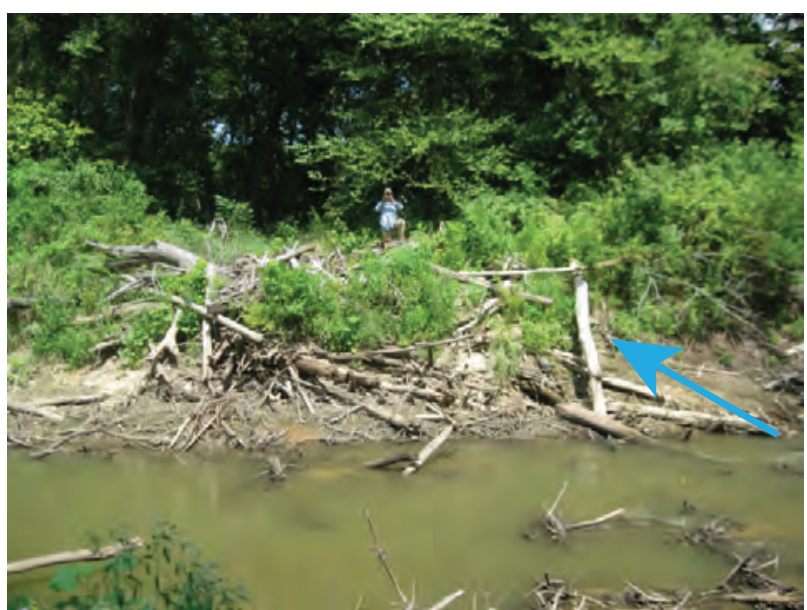

Year 2, 2011, “No change noted at this location. Woody material has not moved." (2 estimated bankfull streamflows in 2011 water year, 12 cumulative).

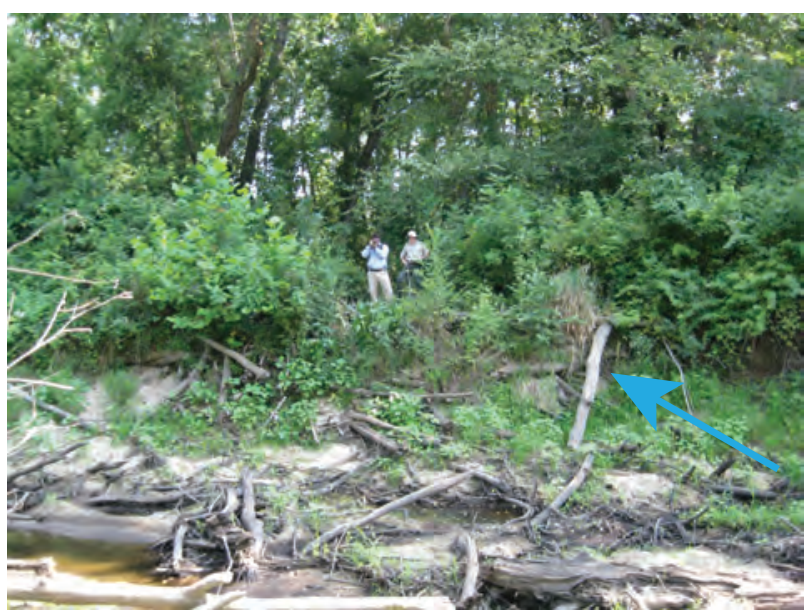

Year 4, 2013, "No changes noted." (5 estimated bankfull streamflows in 2013 water year, 17 cumulative).

Figure 13. Photographs and field notes documenting the status of redistributed large woody debris in the Locust Creek 2009 treatment reach during 2010-13. 


\section{Summary and Conclusions}

The U.S. Geological Survey, in cooperation with the Missouri Department of Natural Resources and Missouri Department of Conservation, completed a study to assess a mechanical redistribution technique used to manage large woody debris (LWD) jams in Locust Creek within Pershing State Park and Fountain Grove Conservation Area, Linn County, Missouri. Extensive LWD jams were treated from 1996 to 2009 using the low-impact technique in which LWD from the jams was redistributed to the inside meander to mimic the natural geomorphic process of channel migration and adjustment to an obstruction. The scope of the study included a comparison of selected channel characteristics, including four channel geometry metrics and bed material particle size, in seven LWD treatment reaches and adjacent untreated (unaffected by LWD accumulations) reaches of Locust Creek. A comparison of 1996 and 2015 survey cross sections in treated and untreated reaches along with photograph documentation were used to assess the stability of redistributed LWD. The physical characteristics of LWD within jams present in the study reach during 2015-16 also were documented.

The hydrology of Locust Creek is an important consideration in managing LWD because it is a primary factor in the transport of material and channel adjustments after treatment. Streamflow diversions on Locust Creek have resulted in four distinct hydrologic reaches within the study area. The streamflow diversions and channel aggradation associated with historical upstream channelization have had substantial effects on the bankfull streamflow capacity and frequency of bankfull flows in the Locust Creek study reaches.

There were no significant differences in the overall distributions of bankfull cross-sectional area, channel width, or streamflow capacity between treated and untreated reaches; however, the overall median width-depth ratio in treated reaches was significantly greater than in untreated reaches. A comparison of these channel metrics of individual treatment reaches with adjacent untreated reaches indicated no significant difference in most (16 of 28) comparisons. Where significant differences in channel metrics were determined between individual reaches, the channel metrics in treated reaches were significantly less than untreated reaches in some cases, and significantly greater than adjacent untreated reaches in others. Channel metrics were more closely correlated with a change in longitudinal channel distance than with the time of treatment, possibly indicating a basin-scale channel control rather than a LWD treatment control. There were no substantial differences in particle-size distribution of channel-bed material in treated and untreated reaches that would indicate obvious differences in competency and sediment transport characteristics between the treated and untreated reaches.

The bankfull streamflow threshold was exceeded an estimated 18 to 25 times in the seven large woody debris treatment reaches since the treatments indicating a substantial opportunity for "geomorphic work" to be done within the channel. Without immediate posttreatment cross sections in treated and untreated reaches for comparison, it is impossible to say with certainty that a lack of significant differences in channel metrics is a result of channel adjustment or, conversely, that any significant differences that remain are a result of treatment. If the lack of significant differences among channel metrics in most treated and untreated reach comparisons is an indication of channel adjustments after treatment, then these adjustments happened despite an increase in streamflow diversions and reduced stream power during the treatment period.

Six cross sections that were surveyed in 1996 before LWD treatment and three cross sections surveyed in 1996 in an untreated reach were compared with 2015 surveys at the same locations to assess stability in the sequestered large woody debris and the channel geometry. Redistributed LWD associated with treatment seems to be intact in the 1996 treated reaches from direct observation and from inference because there was net aggradation between the 1996 and 2015 surveys. The change in channel area resulting from aggradation in time in treated and untreated reaches exceeded the differences between the treated and untreated channels from 2015 surveys. This difference indicates that the reach adjustments to larger scale changes (aggradation downstream from channelized reaches) in the basin with time exceed those differences resulting from the treatment of LWD. Photographs taken annually between 2010 and 2013 after treatment in the 2008 and 2009 treatment reaches also document the stability of LWD in these reaches.

Characteristics of LWD in accumulations sampled within the study area in 2015-16 indicate that most sampled pieces were in the 1-2 foot diameter size class, the 5-16 foot length class, and the advanced decay class. Most documented LWD pieces were loose and not buried, about 20 percent on average had a root wad attached, and about 6.5 percent on average were sawn logs. Characteristics of LWD in accumulations in Pershing State Park indicate most LWD is easily transported and likely sourced from outside of the park. The highly altered Locust Creek system is highly dynamic and in the current (2017) system the reduced streamflow and stream power downstream from the diversions, combined with the recent (2014) formation of an LWD accumulation at the site of the diversions, now substantially limits the transport of material into Pershing State Park.

Based on the general lack of differences in channel metrics between treated and untreated reaches, determined 7-19 years after treatment, it can be concluded that the mechanical redistribution technique has been an effective treatment of LWD in Locust Creek. Given a lack of information on channel metrics immediately after the treatments, the determination of the rate and the specific mechanisms of channel adjustment to treatment were not possible. The conclusion can be drawn despite the complicating effects of channel alterations that have happened in the unchannelized section of Locust Creek including channel aggradation, streamflow piracy, and streamflow diversions. These alterations have resulted in temporal and spatial changes in Locust Creek that 
may affect future applications of the redistribution technique in Pershing State Park. The results indicate that the redistribution technique was used to effectively manage LWD accumulations in Locust Creek at a lower financial cost and reduced environmental disturbance compared to the complete removal of material.

\section{References Cited}

Abbe, T.B., and Montgomery, D.R., 1996, Large woody debris jams, channel hydraulics and habitat formation in large rivers: Regulated Rivers Research and Management, v. 12, p. 201-221.

Alexander, T.W., 1997, Hydraulic analyses of alternative methods for reducing backwater from log jams on Locust Creek near Pershing State Park, Linn County, Missouri: U.S. Geological Survey Open-File Report 97-238, 19 p.

Angermeier, P.L., and Karr, J.R., 1984, Relationships between woody debris and fish habitat in a small warmwater stream: Transactions of the American Fisheries Society, v. 113, p. 716-726.

Barnes, H.H., Jr., 1967, Roughness characteristics of natural channels: U.S. Geological Survey Water-Supply Paper 1849,219 p.

Benham, K.E., 1990, Soil survey of Linn County, Missouri: U.S. Department of Agriculture, Soil Conservation Service, 132 p., accessed June 27, 2017, at https://www.nrcs.usda.gov/Internet/FSE_MANUSCRIPTS/ missouri/MO115/0/linn_MO.pdf

Benke, A.C., Henry, R.L., III, Gillespie, D.M., and Hunter, R.J., 1985, Importance of snag habitat for animal production in southeastern streams: Fisheries, v. 10, p. 8-13.

Bilby, R.E., and Ward, J.W., 1991, Characteristics and function of large woody debris in streams draining old-growth, clearcut, and second-growth forests in southwestern Washington: Canadian Journal of Fisheries and Aquatic Sciences, v. 48, no. 12 , p. 2499-2508.

Cordova, J.M., Rosi-Marshall, E.J., Yamamuro, A.M., and Lamberti, G.A., 2007, Quantity, controls and functions of large woody debris in Midwestern USA streams: River Research and Applications, v. 23, p. 21-33.

Crook, D.A., and Robertson, A.I., 1999, Relationships between riverine fish and woody debris-Implications for lowland rivers: Marine and Freshwater Research, v. 50, p. 941-953.
Downs, P.W., and Simon, Andrew, 2001, Fluvial geomorphological analysis of the recruitment of large woody debris in the Yalobusha River network, Central Mississippi, USA: Geomorphology, v. 37, p. 65-91.

Everett, R.A. and Ruiz, G.M., 1993, Coarse woody debris as refuge from predation in aquatic communities: an experimental test: Oecologia, v. 93, p. 475-486.

Florsheim, J.L., Mount, J.F., and Chin, Anne, 2008, Bank erosion as a desirable attribute of rivers: Bioscience, v. 58, no. 6, p. 519-529.

Frothingham, K.M., Rhoads, B.L., and Herricks, E.E., 2001, Stream geomorphology and fish community structure in channelized and meandering reaches of an agricultural stream, in Dorava, J.M., Montgomery, D.R., Palscak, B.B., and Fitzpatrick, F.A., eds., Geomorphic processes and riverine habitat monograph, Washington, D.C., American Geophysical Union, p. 105-117.

Grantham, L., 1987, Archaeological investigations at Locust Creek Covered Bridge State Historic Site, Linn, County, Missouri: Missouri Department of Natural Resources, Division of Parks, Recreation, and Historic Preservation, Survey Report no. 87-7, 27 p.

Great River Associates, Inc., 2011, Geomorphic engineering assessment of Pershing State Park: Great River Associates, West Plains, Missouri, 19 p.

Gurnell, A.M., Gregory, K.J., and Petts, G.E., 1995, The role of coarse woody debris in forest aquatic habitats-Implications for management. Aquatic Conservation: Marine and Freshwater Ecosystems, v. 5, no. 2, p. 143-166.

Guy, H.P., 1969, Laboratory theory and methods for sediment analyses: U.S. Geological Survey Techniques of WaterResources Investigations, book 5, chap. C1, 58 p.

Guyette, R.P., Cole, W.G., Dey, D.C., and Muzika, R.M., 2002, Perspectives on the age and distribution of large wood in riparian carbon pools: Canadian Journal of Fisheries and Aquatic Science, v. 59, p. 578-585.

Guyette, R.P., Dey, D.C., and Stambaugh, M.C., 2008, The temporal distribution and carbon storage of large oak in streams and floodplain deposits: Ecosystems, v. 11, p. 643-653.

HDR Enginnering, Inc., 2013, North central Missouri Locust Creek watershed study final report: U.S. Army Corps of Engineers, accessed October 3, 2015, at https:/dnr.mo.gov/geology/wrc/docs/nwmo-waterstudy/ Final $\% 20$ Locust $\% 20$ Creek $\% 20$ Watershed $\% 20$ Study $\% 20$ Report\%20November\%2025,\%202013.pdf. 
Helsel, D.R., and Hirsch, R.M., 2002, Statistical methods in water resources: U.S. Geological Survey Techniques of Water-Resources Investigations of the United States Geological Survey, book 4, chap. A3, 510 p.

Homer, C.G., Dewitz, J.A., Yang, Limin, Jin, Suming, Danielson, Patrick, Xian, George, Coulston, John, Herold, N.D., Wickham, J.D., and Megown, Kevin, 2015, Completion of the 2011 National Land Cover Database for the conterminous United States - Representing a decade of land cover change information: Photogrammetric Engineering and Remote Sensing, v. 81, no. 5, p. 345-354, accessed June 22, 2017, at https://www.mrlc.gov/nlcd2011.php.

Hrodey, P.J., Kalb, B.J., and Sutton, T.M., 2008, Macroinvertebrate community response to large-woody debris additions in small warmwater streams: Hydrobiologia, v. 605, p. 193-207.

Hupp, C.R., 1992, Riparian vegetation recovery patterns following stream channelization-A geomorphic perspective: Ecology, v. 73, no. 4, p. 1209-1226.

International Association of Fish and Wildlife Agencies, 1983, Stream obstruction removal guidelines: Stream Renovation Guidelines Committee, Washington, DC., 14 p.

Johnson, L.B., Breneman, D.H., and Richards, Carl, 2003, Macroinvertebrate community structure and function associated with large wood in low gradient streams: River Research and Applications, v. 19, p. 199-218.

Jones, T.A., and Daniels, L.D., 2008, Dynamics of large woody debris in small streams disturbed by the 2001 Dogrib fire in the Alberta foothills: Forest Ecology and Management, v. 256, p. 1751-1759.

Jones, T.A., Daniels, L.D., and Powell, S.R., 2010, Abundance and function of large woody debris in small, headwater streams in the Rocky Mountain foothills of Alberta, Canada: River Research and Applications, v. 27. P. 297-311.

Kendall, M.G., 1975, Rank correlation methods (4th ed.): London, U.K., Charles Griffin., 272 p.

Leopold, L.B., Wolman, M.G., and Miller, J.P., 1964, Fluvial processes in geomorphology: W.H. Freeman and Company, San Francisco, Calif., 522 p.

Martin, D.J., and Benda, L.E., 2001, Patterns of instream wood recruitment and transport at the watershed scale: Transactions of the American Fisheries Society, v 130, p. 940-958.

Montgomery, D.R., Collins, B.D., Buffington, J.M., and Abbe, T.B., 2003, Geomorphic effects of wood in rivers: American Fisheries Society Symposium, v. 37, p. 21-48.
National Oceanic and Atmospheric Administration, 2017, 1981-2010 U.S. climate normals: National Centers for Environmental Information accessed June 20, 2017, at https://www.ncdc.noaa.gov/data-access/land-based-stationdata/land-based-datasets/climate-normals/1981-2010normals-data.

National Research Council, 1991, Committee on Restoration of Aquatic Ecosystems-Science, Technology and Public policy, Restoration of aquatic ecosystems: science, technology and public policy, Water Science and Technology Board, Commission on Geosciences, Environment, and Resources, 540 p.

Natural Resources Conservation Service, 2016, Cross-Section Hydraulic Analyzer, version 17, accessed September 2016, at https://www.nrcs.usda.gov/wps/portal/nrcs/detailfull/ ?cid=stelprdb1042510.

Parker, G., and Andres, D., 1976, Detrimental effects of river channelization. In: Rivers 76: American Society of Civil Engineers: New York, p. 1248-1266.

Pitchford, Greg, and Kerns, Harold, 1998, Grand River watershed inventory and assessment: Missouri Department of Conservation, 85 p. accessed November 10, 2015, at https://mdc.mo.gov/your-property/greener-communities/ missouri-watershed-inventory-and-assessment/grand-river.

Rhoads, B.L., Schwartz, J.S., and Porter, Stacey, 2003, Stream geomorphology, bank vegetation, and three-dimensional habitat hydraulics for fish in Midwestern agricultural streams: Water Resources Research, v. 39, no. 8, p. ESG21ESG213.

Schlosser, I.J., 1991, Stream fish ecology-A landscape perspective: Bioscience, v. 41, p. 704-712.

Sedell, J.R., Bisson, P.A., Swanson, F.T., and Gregory, S.V., 1988, What we know about large trees that fall into streams and rivers, in Maser, G., Tarrant, R.F., Trappe, J.M., and Franklin, J.F. (eds.), From the forest to the sea-A story of fallen trees: U.S. Forest Service, Pacific Northwest Research Station, General Technical Report no. 229, p. $47-81$.

Shields, F.D., Jr., and Nunnally, N.R., 1984, Environmental aspects of clearing and snagging: Journal of Environmental Engineering, v. 110, p. 152-165.

Simon, Andrew, 1989, The discharge of sediment in channelized alluvial streams: Journal of the American Water Resources Association, v. 25, no. 6, p. 1177-1188.

Simon, Andrew, and Rinaldi, Massimo, 2006, Disturbance, stream incision, and channel evolution-The roles of excess transport capacity and boundary materials in controlling channel response: Geomorphology, v. 79, p. 361-383. 
Talmage, P.J., Perry, J.A., and Goldstein, R.M., 2002, Relation of instream habitat and physical conditions to fish communities of agricultural streams in the northern Midwest: North American Journal of Fisheries Management, v. 22, p. $825-833$.

Thom, R.H., and Wilson, J.H., 1980, The natural divisions of Missouri: Transactions of the Missouri Academy of Science, v. 14 p. 9-23.

Trotter, E.H. 1990, Woody debris, forest-stream succession, and catchment geomorphology: Journal of the North American Benthological Society v. 9, p. 141-156.

Turnipseed, D.P., and Sauer, V.B., 2010, Discharge measurements at gaging stations: U.S. Geological Survey Techniques and Methods book 3, chap. A8, 87 p.

U.S. Environmental Protection Agency, 2016, Section 404 of the Clean Water Act, accessed August 11, 2016, at https://www.epa.gov/cwa-404/section-404-permit-program.

U.S. Geological Survey, 2015, Earth Explorer, Digital Orthophoto Quandrangle accessed July 27, 2015, at https://earthexplorer.usgs.gov/.

U.S. Geological Survey, 2017, National Water Information System-Web interface: accessed April 12, 2017, at http://dx.doi.org/10.5066/F7P55KJN. 
For additional information about this publication, contact Director, USGS Missouri Water Science Center 1400 Independence Road

Rolla, MO 65401

(573) 308-3667

Or visit the Missouri Water Science Center website at: https://mo.water.usgs.gov

Publishing support provided by the Rolla Publishing Service Center 

